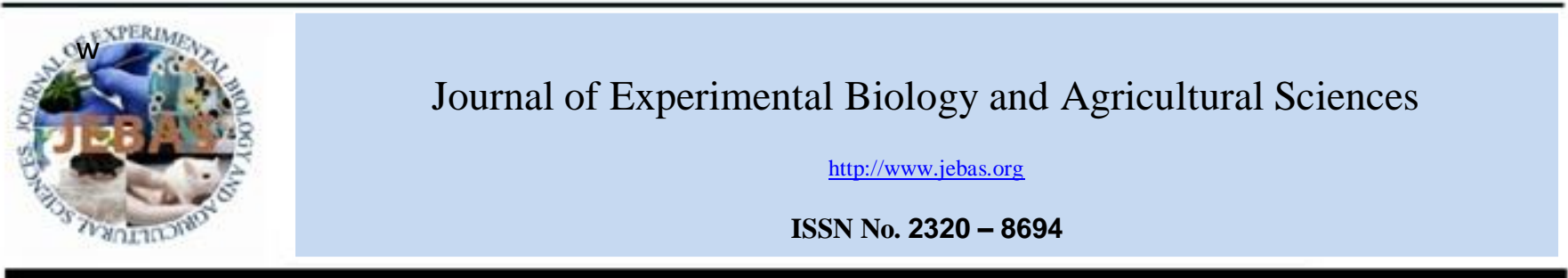

\title{
MULTI TRAIT ANALYSIS REVEALS SUBSTANTIAL DIVERSITY IN PEARL MILLET [Pennisetum glaucum (L.) R. Br.] INBRED LINES
}

\author{
Sonali Sangwan ${ }^{1 *}$, Shikha Yashveer ${ }^{1}$, Ramesh $\mathrm{Kumar}^{2}, \mathrm{Hemender}^{3}$, Sushma Sharma ${ }^{3}$, Neeru Redhu ${ }^{1}$ \\ ${ }^{1}$ Department of Molecular Biology, Biotechnology and Bioinformatics, COBS\&H. \\ ${ }^{2}$ Bajra Section, Department of Genetics and Plant Breeding, COA. \\ ${ }^{3}$ Department of Seed Science and Technology, COA, Chaudhary Charan Singh Haryana Agricultural University, Hisar-125001, Haryana, India.
}

Received - April 17, 2019; Revision - June 08, 2019; Accepted - July 16, 2019

Available Online - August 05, 2019

DOI: http://dx.doi.org/10.18006/2019.7(4).358.375

KEYWORDS
Pearl millet
Morphology
Iron
Zinc
Genetic variability
Simple Sequence Repeat
Genetic diversity

\begin{abstract}
The strength of any ongoing breeding programme thoroughly depends on the presence of genetic variation at both morphological and molecular level. In present study, total 36 pearl millet genotypes were evaluated for different morphological characters along with grain $\mathrm{Fe}$ and $\mathrm{Zn}$ contents. High estimates of coefficient of variation inclusive of high heritability and genetic advance as per cent of mean was marked for dry fodder yield per plant, grain yield per plant, Fe and $\mathrm{Zn}$ contents. This suggested that the selection based on these traits will be effective in improving breeding material. Further correlation analysis showed a highly significant correlation between grain $\mathrm{Fe}$ and $\mathrm{Zn}$ content which signifies simultaneous improvement in the two traits. Grain yield per plant showed non significant negative correlation with $\mathrm{Fe}$ and $\mathrm{Zn}$ thus suggesting improvement in nutrient value without sacrificing yield. A set of 64 SSRs was also used for molecular diversity assessment. A significant positive correlation was observed among number of alleles, Polymorphic Information Content (PIC) and number of repeats in the SSR motifs. Across the linkage groups, the mean PIC varied from 0.48 (LG 3) to 0.76 (LG 2). Mean alleles per locus and overall PIC obtained was 7.20 and 0.68 respectively. Presence of ample variation at morpho-genetic level signifies their use as parents in the out crossing programmes to obtain new improved hybrids with desired traits.
\end{abstract}

* Corresponding author

E-mail: sonalisangwan03@gmail.com (Sonali Sangwan)

Peer review under responsibility of Journal of Experimental Biology and Agricultural Sciences.

Production and Hosting by Horizon Publisher India [HPI] (http://www.horizonpublisherindia.in/).

All rights reserved.
All the articles published by Journal of Experimental Biology and Agricultural Sciences are licensed under a Creative Commons Attribution-NonCommercial 4.0 International License Based on a work at www.jebas.org.

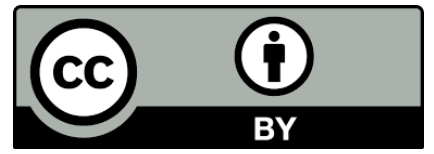




\section{Introduction}

Pearl millet [Pennisetum glaucum (L.) R. Br.] is a highly cross pollinated $\mathrm{C}_{4}$ monocot species belonging to the family Poaceae. It has a relatively small genome $(2 n=2 x=14)$ with a DNA content of $1 \mathrm{C}=2.36 \mathrm{pg}$ (Martel et al., 1997). An estimated 30 million ha is cultivated with pearl millet in the arid and semiarid tropical regions of Asia, Africa and Latin America (Yadav \& Rai, 2013). India is the largest producer of pearl millet in Asia, both in terms of area (about 9 million ha) and production (8.3 million tons) with an average productivity of $930 \mathrm{~kg} / \mathrm{ha}$ (AICPMIP, 2017). It is a crop of area characterized with low and erratic rainfall (200-600 $\mathrm{mm}$ ), high temperature, high salinity or low $\mathrm{pH}$ and impoverished infertile soils. Because of its tolerance to harsh growing conditions, it can be grown in areas where other cereal crops, such as wheat, maize or rice would not survive. Also, high protein and oil content, gluten free nature and richness in vitamin B (especially niacin, B6, folic acid), calcium, potassium, magnesium and other essential micronutrients have made its production popular from being a neglected 'orphan' crop earlier.

Knowledge for the extent of genetic variation among breeding material (germplasm, breeding lines \& inbred lines) is essential to understand the pattern of diversity and evolutionary relationship among them. This is also helpful to efficiently use germplasm in crop improvement program (Wu et al., 2007; Thiyagu et al., 2011). Pearl millet has been found to exhibit a wide range of morphological variability for several traits such as plant height, days to $50 \%$ flowering, panicle length and width, grain yield and nutritional value (Haussmann et al., 2006; Bhattacharjee et al., 2007; Stich et al., 2010; Bashir et al., 2014). The assessment of genetic diversity on the basis of morphological characteristics alone might not provide accurate information. It is due to the restricted number of morphological traits evaluated, environmental influence and development-specific trait expression. All these factors thus necessitate application of molecular markers for having a better view of genetic diversity present among the breeding material.

In pearl millet, the first application of molecular markers was creation of genetic linkage map using Restriction Fragment Length Polymorphism (RFLP) (Liu et al., 1994). Later, sequence independent PCR based markers like RAPD, ISSR, AFLP and microsatellite probes have been used for genetic diversity studies (Chowdari et al., 1998; vomBrocke et al., 2003; Yadav et al., 2007; Govindaraj et al., 2009). Meanwhile, development of SSR markers (Allouis et al., 2001; Qi et al., 2001) and their use in genetic diversity and gene mapping studies succeeded (Mariac et al., 2006; Chandra-Shekhra et al., 2007). Microsatellite markers have been adjudged as more effective and reliable DNA markers for such studies (Kapila et al., 2008) because of their abundance in genome, multi allelism, genome specificity, even distribution, high polymorphism, easy detection, high-throughput, highly reproducible and co-dominantly inherited behavior (Hernandez et al., 2002).

Worldwide serious and widespread human health problems have been recognized due to dietary deficiency of mineral micronutrients such as iron and zinc (WHO, 2002; Welch \& Graham, 2004). Micronutrient malnutrition increases mortality \& morbidity rates and health-care costs, reduces labor productivity, and thus impacts on national developmental efforts (Darnton-Hill et al., 2005; Stein, 2010). The developing and under-developed countries of Africa and Asia are worst affected by malnutrition. These regions grow pearl millet as staple for dietary energy. Genetic resources of pearl millet are untapped and need attempts to improve the iron and zinc content. Discerning the genetic diversity of these traits and characterizing genotypes with advent of conventional as well as by molecular markers will be useful to identify contrasting parental materials to enhance heterozygosity or to optimize the genetic heterogeneity in a hybrid population and enhance yield stability along with nutrient value in variable and changing climates (Haussmann et al., 2007; Hausmann et al., 2012). Keeping all this in mind, present study was conducted to understand genetic diversity existing at morpho-biochemical and molecular level among pearl millet inbred lines.

\section{Materials and methods}

\subsection{Raising of crop}

Seeds of 36 pearl millet genotypes (Table 1) were obtained from Bajra section, Department of Genetics and Plant Breeding, CCSHAU, Hisar. The crop was grown in Randomized Block Design with two replications in two environments [normal-sown (NS) and late-sown(LS)] at the research area of Bajra section with a plot size 2 rows $x 4 \mathrm{~m} \times 0.5 \mathrm{~m}$ and $10-12 \mathrm{~cm}$ intra-row spacing. The research site is located at $29^{\circ} 17^{\prime} \mathrm{N}$ latitude and $75^{\circ}$ $47^{\prime} \mathrm{E}$ longitude at an altitude of 215.2 meters above mean sea level in the subtropical climatic zone of India and a sandy-loam soil type. All recommended agronomic practices were followed for raising a good crop. Seven characters were selected for morphological studies namely, days to $50 \%$ flowering, plant height, ear length, ear diameter, 1000 grain weight, grain yield per plant and dry fodder yield per plant. All these traits were measured on individual plant and the data was analyzed as means of 5 individual plants from each line. On harvest, openpollinated grains were used for analysis of $\mathrm{Fe}$ and $\mathrm{Zn}$ content using X-ray Fluorescence Spectroscopy (XRF) technique at ICRISAT (Paltridge et al., 2012). 
Table 1 Pearl millet genotypes used in the present study

\begin{tabular}{|c|c|c|c|}
\hline S. No. & Genotypes & S. No. & Genotypes \\
\hline 1. & HMS 48B & 19. & AC-04/7 \\
\hline 2. & HMS 14B & 20. & Н 2302 \\
\hline 3. & HMS 58B & 21. & $72-2-2 / 98 \mathrm{~K}-1$ \\
\hline 4. & HMS 53B & 22. & НТР 93/109 \\
\hline 5. & HMS 55B & 23. & НТР 98-2 \\
\hline 6. & HMS 43B & 24. & Н 78/711 \\
\hline 7. & HMS 60B & 25. & H 10/4-7 \\
\hline 8. & HMS 7B & 26. & H $10 / 10-2$ \\
\hline 9. & HMS 44B & 27. & НТР 94/54 \\
\hline 10. & HMS 22B & 28. & НТР 98/3 \\
\hline 11. & HMS 16B & 29. & НTP 92/80 \\
\hline 12. & HMS 38B & 30. & TCH 26-1 \\
\hline 13. & HMS 37B & 31. & H 94/46 \\
\hline 14. & HMS 26B & 32. & HBL 11 \\
\hline 15. & HMS 30B & 33. & AC-04/13 \\
\hline 16. & H 72-2-2 & 34. & H 12/1009 \\
\hline 17. & H 12/009 & 35. & 99 HS 139 \\
\hline 18. & H $12 / 008$ & 36. & 99 HS-23 \\
\hline
\end{tabular}

\subsection{DNA extraction and PCR assay}

Young and fresh leaves of 30 days old plants were used for DNA extraction. Genomic DNA was isolated using CTAB extraction method of Saghai-Maroof et al. (1984) with little modifications. RNase treatment was given to purify the extracted DNA. Isolated DNA from each genotype was run in $0.8 \%$ agarose gel and analyzed using UV spectrophotometer (Elico Ltd., India). A total of 71 SSR primer pairs (Imperial Life Sciences, USA) comprising of genomic as well as EST-SSRs were selected on the basis of previous studies (Allouis et al., 2001; Qi et al., 2001; Budak et al., 2003; Qi et al., 2004; Mariac et al., 2006; Yadav et al., 2007; Senthilvel et al., 2008) to study molecular diversity among genotypes encompassing at least two SSR loci from each linkage group, representing the whole nuclear genome. PCR amplifications were performed using G-storm thermocycler in 20 $\mu 1$ reaction mixture containing $1 \mu 150$ ng DNA, $1 \mu 1$ DMSO, 1.25X PCR buffer, $0.25 \mathrm{mM}$ dNTPs, $0.125 \mu \mathrm{M}$ forward and reverse primers, $2.5 \mathrm{U}$ taq DNA polymerase. Touch-down amplifying program for PCR cycles was used which consisted of initial denaturation at $94^{\circ} \mathrm{C}$ for $3 \mathrm{~min}, 5$ cycles of denaturation at $94^{\circ} \mathrm{C}$ for $45 \mathrm{sec}$, annealing at $46-61^{\circ} \mathrm{C}$ (depending on primer) for 1 min, extension at $72^{\circ} \mathrm{C}$ for $45 \mathrm{sec}$; then 20 cycles consisting of denaturation at $94^{\circ} \mathrm{C}$ for $45 \mathrm{sec}$, annealing at $44-59^{\circ} \mathrm{C}$ for $1 \mathrm{~min}$, extension at $72^{\circ} \mathrm{C}$ for $45 \mathrm{sec}$ and a final extension at $72^{\circ} \mathrm{C}$ for 10 min. Amplified PCR products $(10 \mu \mathrm{l})$ were separated on ethidium bromide stained $6 \%$ polyacrylamide gel (C.B.S. Scientific, USA) at $220 \mathrm{~V}$ for 3 hours in $0.5 \mathrm{X}$ Tris- Borate EDTA buffer. The DNA bands were visualized and photographed under UV light using gel documentation system (UVP, USA). The experiments were repeated at least twice to confirm the results and check for the reproducibility of the amplified products.

\subsection{Statistical and Molecular Data Analysis}

All statistical analysis of recorded phenotypic data was performed using OPSTAT software (Sheron et al., 1998 available at http://www.hau.ac.in). Cluster analysis of morphological characters as well as Fe and $\mathrm{Zn}$ content was done based on Ward's Minimum Variance method using IndoStat software (developed by IndoStat service, Hyderabad). For molecular analysis clearly resolved bands were scored for presence (1) or absence (0). The size (in nucleotide base pairs) of the most intensely amplified reproducible and unambiguous bands for each microsatellite marker was determined based on its migration relative to a standard DNA marker (20 or 100 bp G-biosciences DNA ladder). Multiple alleles were inferred whenever a given marker produced more than one cluster of bands. The binary data matrix generated was then used to calculate pair-wise similarity coefficient for all possible pairs of genotypes using Jaccard's similarity coefficient (Jaccard, 1908). 'Simqual' subprogram of software NTSYS-pc version 2.02e (Rohlf, 2000) was used to generate similarity matrix. Cluster analysis was done using 'SAHN' sub-program and dendrogram was then constructed based on UPGMA algorithm. Furthermore, matrix was subjected to Principal Component Analysis (PCA) for the three principal components using 'Eigen' subprogram to generate a 2-D and 3-D representation of genetic relationship among the genotypes. WinBoot software program (Yap \& Nelson, 2002) was also used to verify the clusters obtained by NTSYS-pc.

\section{Results and Discussion}

\subsection{Estimates of Variability}

The analysis of variance revealed that the mean sum of squares showed highly significant differences among the genotypes for the various characters studied in two environments (data not shown). The estimates of variability parameters for all the characters are shown in the Table 2. A wide range of differences for Genotypic Coefficient of Variation (GCV) was observed which varied from 7.54 for days to $50 \%$ flowering to 39.19 for dry fodder yield per plant in NS and 7.70 for days to $50 \%$ flowering to 41.19 for dry 
Table 2 Estimates of variability parameters for different characters in thirty-six pearl millet genotypes grown during kharif

\begin{tabular}{|c|c|c|c|c|c|c|c|c|c|c|c|c|c|c|c|}
\hline \multirow[t]{2}{*}{$\begin{array}{l}\text { S. } \\
\text { No. }\end{array}$} & \multirow[t]{2}{*}{ Character } & \multicolumn{2}{|c|}{ Mean \pm SE(d) } & \multicolumn{2}{|c|}{ Range } & \multicolumn{2}{|c|}{ GCV } & \multicolumn{2}{|c|}{ PCV } & \multicolumn{2}{|c|}{$\begin{array}{l}\text { Heritability } \\
(\%)\end{array}$} & \multicolumn{2}{|c|}{$\begin{array}{l}\text { Genetic } \\
\text { advance }\end{array}$} & \multicolumn{2}{|c|}{$\begin{array}{c}\text { Genetic } \\
\text { advance (\% } \\
\text { of mean) }\end{array}$} \\
\hline & & NS & LS & NS & LS & NS & LS & NS & LS & NS & LS & NS & LS & NS & LS \\
\hline 1 & $\begin{array}{c}\text { Days to } 50 \% \\
\text { Flowering }\end{array}$ & $53.10 \pm 0.73$ & $50.20 \pm 01.42$ & $42.50-60.50$ & $39.00-57.50$ & 07.54 & 07.70 & 07.66 & 08.21 & 96.76 & 88.14 & 08.11 & 07.48 & 15.27 & 14.90 \\
\hline 2 & $\begin{array}{l}\text { Plant height } \\
(\mathrm{cm})\end{array}$ & $145.50 \pm 07.27$ & $127.00 \pm 07.14$ & $83.70-221.00$ & $53.50-205.50$ & 21.46 & 23.94 & 22.03 & 24.59 & 94.87 & 94.78 & 62.66 & 60.96 & 43.06 & 48.02 \\
\hline 3 & $\begin{array}{c}\text { Ear length } \\
(\mathrm{cm})\end{array}$ & $19.80 \pm 01.56$ & $18.00 \pm 01.32$ & $12.80-32.00$ & $13.60-27.50$ & 17.40 & 15.89 & 19.11 & 17.51 & 82.96 & 82.43 & 06.48 & 05.36 & 32.66 & 29.72 \\
\hline 4 & $\begin{array}{c}\text { Ear diameter } \\
(\mathrm{cm})\end{array}$ & $2.20 \pm 00.16$ & $2.00 \pm 00.22$ & $01.58-02.70$ & $01.45-02.60$ & 12.87 & 13.08 & 14.76 & 16.94 & 76.05 & 59.59 & 00.50 & 00.42 & 23.12 & 20.79 \\
\hline 5 & $\begin{array}{l}1000 \text { grain } \\
\text { weight }(\mathrm{g})\end{array}$ & $7.90 \pm 00.75$ & $7.40 \pm 01.31$ & 03.92-12.65 & 03.74-12.25 & 19.78 & 19.76 & 21.89 & 26.46 & 81.64 & 55.77 & 02.93 & 02.26 & 36.82 & 30.40 \\
\hline 6 & $\begin{array}{l}\text { Grain yield } \\
\text { per plant }(\mathrm{g})\end{array}$ & $21.10 \pm 02.38$ & $14.20 \pm 02.30$ & $07.23-33.15$ & $04.40-24.20$ & 34.84 & 34.44 & 36.61 & 38.07 & 90.55 & 81.81 & 14.44 & 09.10 & 68.29 & 64.16 \\
\hline 7 & $\begin{array}{l}\text { Dry fodder } \\
\text { yield per plant } \\
(\mathrm{g})\end{array}$ & $59.80 \pm 06.22$ & $43.10 \pm 06.04$ & $16.80-120.00$ & $17.04-86.80$ & 39.19 & 41.19 & 40.55 & 43.51 & 93.42 & 89.63 & 46.66 & 34.63 & 78.04 & 80.33 \\
\hline 8 & $\begin{array}{c}\text { Fe content } \\
(\mathrm{ppm})\end{array}$ & $53.57 \pm 09.41$ & $59.00 \pm 06.34$ & $29.00-93.50$ & $33.50-108.00$ & 34.46 & 34.22 & 38.67 & 35.87 & 79.39 & 91.04 & 33.88 & 39.69 & 63.24 & 67.26 \\
\hline 9 & $\begin{array}{c}\text { Zn content } \\
(\mathrm{ppm})\end{array}$ & $40.39 \pm 07.40$ & $42.13 \pm 06.65$ & $23.00-81.00$ & $23.00-75.00$ & 29.79 & 31.97 & 34.98 & 35.65 & 72.53 & 80.39 & 21.11 & 24.87 & 52.26 & 59.04 \\
\hline
\end{tabular}

NS- Normal-sown environment; LS- Late-sown environment

fodder yield per plant in LS. Phenotypic Coefficient of Variation (PCV) varied from 7.66 for days to $50 \%$ flowering to 40.55 for dry fodder yield per plant in NS and 8.21 for days to $50 \%$ flowering to 43.51 for dry fodder yield per plant in LS. The presence of wide range of GCV and PCV for all the characters indicated the presence of considerable amount of variability among the genotypes. GCV and PCV values were highest for dry fodder yield per plant in both the environments followed by grain yield per plant then $\mathrm{Fe} \& \mathrm{Zn}$ content indicating availability of sufficient variation and thus, scope for genetic improvement through selection for all these traits. Days to $50 \%$ flowering exhibited least GCV and PCV in both the environments as also studied by Lakshmana et al. (2010), Choudhary et al. (2012) and Kumar et al. (2014). A higher PCV of characters than their corresponding GCV was observed in present study. This suggested the role of environment in the expression of all these characters. Kumar et al. (2014) also observed higher PCV than GCV for the studied characters.

A wide range for heritability in broad sense, genetic advance and genetic advance in terms of per cent of mean was noticed in both the environments. Estimates of heritability in broad sense ranged from $72.53 \%$ for $\mathrm{Zn}$ content to $96.76 \%$ for days to $50 \%$ flowering and $55.77 \%$ for 1000 grain weight to $94.78 \%$ for plant height in NS and LS respectively. Range for genetic advance in terms of per cent of mean varied from 15.27 and 14.90 for days to $50 \%$ flowering to 78.04 and 80.33 for dry fodder yield per plant in NS and LS respectively. High estimates of coefficient of variation along with moderate to high heritability and genetic advance as per cent of mean for dry fodder yield per plant, grain yield per plant, Fe and $\mathrm{Zn}$ contents are indicative of additive gene action for these characters. These traits are thus more reliable for effective selection in improving the plant performance. High heritability and genetic advance per cent of mean was also reported by Bhoite et al. (2008) and Bind et al. (2015) for dry fodder yield per plant and grain yield per plant suggesting their reliability for effective selection. Ear length, ear diameter and 1000 grain weight had moderate heritability and genetic advance which indicated both additive and non-additive gene effects that makes use of reciprocal recurrent selection. In the present study, higher values of heritability and lower values of genetic advance and variability were observed for days to $50 \%$ flowering, signaling towards the presence of nonadditive gene actions. The most favorable breeding strategy for improvement in such traits can be the selection at later stages.

\subsection{Correlation Coefficient analysis}

Phenotypic and genotypic correlation coefficient analysis was carried out to assess the association between various traits (Table 3). Fe content ( $\mathrm{ppm})$ showed a significant positive correlation with 1000 grain weight at genotypic $(r=0.282 ; \mathrm{p}=0.05)$ level and dry fodder yield per plant at both phenotypic $(r=0.278 ; \mathrm{p}=0.05)$ and genotypic $(r=0.282 ; p=0.05)$ level in LS. A significant negative correlation of Fe content with plant height at genotypic $(r=-0.269 ; p=0.05)$ level and with ear length at both phenotypic $(r=-0.266 ; p=0.05)$ and genotypic $(r=-0.315 ; p=0.01)$ level was observed in NS. Zn content showed a significant positive correlation with 1000 grain weight at genotypic $(r=0.272 ; \mathrm{p}=0.05)$ level in NS and at phenotypic $(\mathrm{r}=0.240 ; \mathrm{p}=0.05)$ as well as at genotypic $(\mathrm{r}=0.398$; $\mathrm{p}=0.01)$ level in LS. $\mathrm{Zn}$ content also exhibited significant positive 
Table 3: Phenotypic and genotypic correlation coefficients among nine characters in thirty-six pearl millet genotypes grown during kharif

\begin{tabular}{|c|c|c|c|c|c|c|c|c|c|c|c|}
\hline Character & & & $\begin{array}{c}\text { Days to } \\
50 \% \\
\text { flowering }\end{array}$ & $\begin{array}{l}\text { Plant } \\
\text { height } \\
(\mathrm{cm})\end{array}$ & $\begin{array}{c}\text { Ear } \\
\text { length } \\
(\mathrm{cm})\end{array}$ & $\begin{array}{c}\text { Ear } \\
\text { diameter } \\
(\mathrm{cm})\end{array}$ & $\begin{array}{c}1000 \\
\text { grain } \\
\text { weight } \\
(\mathrm{g})\end{array}$ & $\begin{array}{l}\text { Grain } \\
\text { yield (g) }\end{array}$ & $\begin{array}{c}\text { Dry } \\
\text { fodder } \\
\text { yield }(\mathrm{g})\end{array}$ & $\begin{array}{c}\mathrm{Fe} \\
(\mathrm{ppm})\end{array}$ & $\begin{array}{c}\mathrm{Zn} \\
(\mathrm{ppm})\end{array}$ \\
\hline \multirow{4}{*}{$\begin{array}{l}\text { Days to } \\
50 \% \\
\text { flowering }\end{array}$} & \multirow{2}{*}{ NS } & $\mathrm{P}$ & 1.000 & & & & & & & & \\
\hline & & G & 1.000 & & & & & & & & \\
\hline & \multirow{2}{*}{ LS } & $\mathrm{P}$ & 1.000 & & & & & & & & \\
\hline & & G & 1.000 & & & & & & & & \\
\hline \multirow{4}{*}{$\begin{array}{l}\text { Plant } \\
\text { height } \\
(\mathrm{cm})\end{array}$} & \multirow{2}{*}{ NS } & $\mathrm{P}$ & $-0.240 *$ & 1.000 & & & & & & & \\
\hline & & G & $-0.250 *$ & 1.000 & & & & & & & \\
\hline & \multirow{2}{*}{ LS } & $\mathrm{P}$ & $-0.283 *$ & 1.000 & & & & & & & \\
\hline & & G & $-0.293 *$ & 1.000 & & & & & & & \\
\hline \multirow{4}{*}{$\begin{array}{l}\text { Ear length } \\
\quad(\mathrm{cm})\end{array}$} & \multirow{2}{*}{ NS } & $\mathrm{P}$ & $-0.098 \mathrm{NS}$ & $0.459^{* *}$ & 1.000 & & & & & & \\
\hline & & G & $-0.108 \mathrm{NS}$ & $0.463 * *$ & 1.000 & & & & & & \\
\hline & \multirow{2}{*}{ LS } & $\mathrm{P}$ & $-0.155 \mathrm{NS}$ & $0.430^{* *}$ & 1.000 & & & & & & \\
\hline & & G & $-0.210 \mathrm{NS}$ & $0.465^{* *}$ & 1.000 & & & & & & \\
\hline \multirow{4}{*}{$\begin{array}{c}\text { Ear } \\
\text { diameter } \\
(\mathrm{cm})\end{array}$} & \multirow{2}{*}{ NS } & $\mathrm{P}$ & $-0.072 \mathrm{NS}$ & $0.122 \mathrm{NS}$ & $0.249^{*}$ & 1.000 & & & & & \\
\hline & & G & $-0.081 \mathrm{NS}$ & $0.134 \mathrm{NS}$ & $0.227 \mathrm{NS}$ & 1.000 & & & & & \\
\hline & \multirow{2}{*}{ LS } & $\mathrm{P}$ & $-0.044 \mathrm{NS}$ & $0.257^{*}$ & $0.426 * *$ & 1.000 & & & & & \\
\hline & & G & $-0.053 \mathrm{NS}$ & $0.317^{* *}$ & $0.522 * *$ & 1.000 & & & & & \\
\hline \multirow{4}{*}{$\begin{array}{l}1000 \text { grain } \\
\text { weight (g) }\end{array}$} & \multirow{2}{*}{ NS } & $\mathrm{P}$ & $-0.034 \mathrm{NS}$ & $0.324 * *$ & $0.209 \mathrm{NS}$ & $0.495 * *$ & 1.000 & & & & \\
\hline & & G & $-0.053 \mathrm{NS}$ & $0.332^{* *}$ & $0.236^{*}$ & $0.544 * *$ & 1.000 & & & & \\
\hline & \multirow{2}{*}{ LS } & $\mathrm{P}$ & $-0.327 * *$ & $0.513^{* *}$ & $0.242^{*}$ & $0.289 *$ & 1.000 & & & & \\
\hline & & G & $-0.461 * *$ & $0.640^{* *}$ & $0.289^{*}$ & $0.247 *$ & 1.000 & & & & \\
\hline \multirow{4}{*}{$\begin{array}{l}\text { Grain yield } \\
(\mathrm{g})\end{array}$} & \multirow{2}{*}{ NS } & $\mathrm{P}$ & $-0.121 \mathrm{NS}$ & $0.295^{*}$ & $0.495 * *$ & $0.322 * *$ & $0.334 * *$ & 1.000 & & & \\
\hline & & G & $-0.128 \mathrm{NS}$ & $0.292^{*}$ & $0.496 * *$ & $0.328^{* *}$ & $0.365^{* *}$ & 1.000 & & & \\
\hline & \multirow{2}{*}{ LS } & $\mathrm{P}$ & $-0.372 * *$ & $0.644 * *$ & $0.472 * *$ & $0.395 * *$ & $0.577 * *$ & 1.000 & & & \\
\hline & & G & $-0.445 * *$ & $0.723 * *$ & $0.565 * *$ & $0.509 * *$ & $0.707 * *$ & 1.000 & & & \\
\hline \multirow{4}{*}{$\begin{array}{l}\text { Dry fodder } \\
\text { yield }(\mathrm{g})\end{array}$} & \multirow{2}{*}{ NS } & $\mathrm{P}$ & $-0.007 \mathrm{NS}$ & $0.331^{* *}$ & $0.320 * *$ & $0.278^{*}$ & $0.425 * *$ & $0.717 * *$ & 1.000 & & \\
\hline & & G & $0.001 \mathrm{NS}$ & $0.331 * *$ & $0.307 * *$ & $0.276^{*}$ & $0.475 * *$ & $0.712 * *$ & 1.000 & & \\
\hline & \multirow{2}{*}{ LS } & $\mathrm{P}$ & $-0.363 * *$ & $0.533^{* *}$ & $0.308 * *$ & $0.212 \mathrm{NS}$ & $0.528 * *$ & $0.757 * *$ & 1.000 & & \\
\hline & & G & $-0.416^{* *}$ & $0.558^{* *}$ & $0.340 * *$ & $0.234 *$ & $0.652 * *$ & $0.802^{* *}$ & 1.000 & & \\
\hline \multirow{4}{*}{$\mathrm{Fe}(\mathrm{ppm})$} & \multirow{2}{*}{ NS } & $\mathrm{P}$ & $-0.016 \mathrm{NS}$ & $-0.217 \mathrm{NS}$ & $-0.266^{*}$ & $0.171 \mathrm{NS}$ & $0.217 \mathrm{NS}$ & $0.125 \mathrm{NS}$ & $0.058 \mathrm{NS}$ & 1.000 & \\
\hline & & G & $-0.024 \mathrm{NS}$ & $-0.269^{*}$ & $-0.315^{* *}$ & $0.223 \mathrm{NS}$ & $0.216 \mathrm{NS}$ & $0.141 \mathrm{NS}$ & $0.071 \mathrm{NS}$ & 1.000 & \\
\hline & \multirow{2}{*}{ LS } & $\mathrm{P}$ & $-0.170 \mathrm{NS}$ & $-0.012 \mathrm{NS}$ & $-0.078 \mathrm{NS}$ & $0.070 \mathrm{NS}$ & $0.166 \mathrm{NS}$ & $0.002 \mathrm{NS}$ & $0.278^{*}$ & 1.000 & \\
\hline & & G & $-0.180 \mathrm{NS}$ & $-0.016 \mathrm{NS}$ & $-0.035 \mathrm{NS}$ & $0.166 \mathrm{NS}$ & $0.282 *$ & $0.031 \mathrm{NS}$ & $0.282^{*}$ & 1.000 & \\
\hline \multirow{4}{*}{$\mathrm{Zn}(\mathrm{ppm})$} & NS & $\mathrm{P}$ & $-0.050 \mathrm{NS}$ & $-0.153 \mathrm{NS}$ & $-0.372 * *$ & $0.109 \mathrm{NS}$ & $0.224 \mathrm{NS}$ & $0.198 \mathrm{NS}$ & $0.053 \mathrm{NS}$ & $0.873 * *$ & 1.000 \\
\hline & SO & G & $-0.062 \mathrm{NS}$ & $-0.208 \mathrm{NS}$ & $-0.469 * *$ & $0.144 \mathrm{NS}$ & $0.272^{*}$ & $0.212 \mathrm{NS}$ & $0.070 \mathrm{NS}$ & $0.899 * *$ & 1.000 \\
\hline & I S & $\mathrm{P}$ & $-0.267 *$ & $0.113 \mathrm{NS}$ & $-0.152 \mathrm{NS}$ & $-0.101 \mathrm{NS}$ & $0.240^{*}$ & $0.006 \mathrm{NS}$ & $0.252^{*}$ & $0.847 * *$ & 1.000 \\
\hline & & G & $-0.322 * *$ & $0.127 \mathrm{NS}$ & $-0.139 \mathrm{NS}$ & $-0.078 \mathrm{NS}$ & $0.398 * *$ & $0.105 \mathrm{NS}$ & $0.308^{* *}$ & $0.914 * *$ & 1.000 \\
\hline
\end{tabular}

*** Significant at $P=0.05$ and $P=0.01$ levels respectively; P-Phenotypic correlation coefficient values;

$G$ - Genotypic correlation coefficient values; NS-Non Significant 
correlation with dry fodder yield at both phenotypic $(\mathrm{r}=0.252 ; \mathrm{p}$ $=0.05)$ and genotypic $(r=0.308 ; p=0.01)$ levels in LS. A highly significant positive correlation between $\mathrm{Fe}$ and $\mathrm{Zn}$ content in the two environments at phenotypic $(r=0.873 ; p=0.01, r=0.847 ; p$ $=0.01)$ as well as genotypic $(\mathrm{r}=0.899 ; \mathrm{p}=0.01, \mathrm{r}=0.914 ; \mathrm{p}=$ $0.01)$ levels was observed in this study. Earlier studies on pearl millet by Velu et al. (2007, 2008a, 2008b), Gupta et al. (2009), Govindaraj et al. $(2012,2013)$ and Rai et al. $(2012,2013,2015)$ also showed a highly significant and positive correlation between the levels of $\mathrm{Fe}$ and $\mathrm{Zn}$ contents. Similar relationship between these two mineral elements has also been reported in other cereals such as finger millet (Upadhyaya et al., 2011), sorghum (Kumar et al., 2009, 2013), maize (Oikeh et al., 2003, 2004), rice (Anandan et al., 2011) and wheat (Garvin et al., 2006; Velu et al., 2011). This positive correlation could be due to common and overlapping quantitative trait loci (QTL) for grain $\mathrm{Fe}$ and $\mathrm{Zn}$ contents as reported in pearl millet (Kumar, 2011), wheat (Peleg et al., 2009; Singh et al., 2010), rice (Stangoulis et al., 2007) and common bean (Blair et al., 2009; Cichy et al., 2009).

In order to realize maximum impact of micronutrient-rich cultivars, the micronutrients must be delivered in high-yielding cultivars with farmer's preferred traits such as large seed size and yield. Fe content showed a significant but weak positive correlation with 1000 grain weight at only genotypic $(r=0.282 ; \mathrm{p}$ $=0.05)$ level in LS. Zn content also showed positive correlation with 1000 grain weight at genotypic $(r=0.272 ; \mathrm{p}=0.05)$ level in NS and at phenotypic $(r=0.240 ; p=0.005)$ as well as genotypic $(r=0.398 ; p=0.01)$ levels in LS. It is in concordance with correlation observed by Velu et al. (2008b) and Kanatti et al. (2014) in pearl millet hybrids. A significant moderate to high correlation was also observed by Velu et al. $(2007,2008 \mathrm{~b})$ in their studies. However, a non significant correlation observed between $\mathrm{Fe}$ content and 1000 grain weight at both levels in NS and at phenotypic level in LS is in concordance with results of Velu et al. (2008a), Gupta et al. (2009), Govindaraj et al. (2012), Rai et al. (2012, 2013, 2015) and Kanatti et al. (2014). Early maturity is another farmer preferred trait that enables the crop to escape terminal drought stress in short season environments and permits double cropping. Correlation observed between $\mathrm{Fe}$ and days to $50 \%$ flowering was non significant at both the levels in both the environments. Similar results were observed in studies of Velu et al. (2008a) and Rai et al. (2012, 2015). However, study of Velu et al. (2008b) reported negative correlation between Fe and days to $50 \%$ flowering. Non significant correlation observed between $\mathrm{Zn}$ content and days to $50 \%$ flowering at both the levels in NS is similar to the results of Velu et al. (2008a, 2008b) and Rai et al. (2012, 2015). None of the earlier studies presented significant negative correlation as observed in this study between $\mathrm{Zn}$ content and days to $50 \%$ flowering at phenotypic $(r=-0.267 ; p=0.05)$ as well as genotypic $(r=-0.332 ; p=0.01)$ levels in LS.
For any biofortification programme, an important aspect is to take care that nutrient value enhancement should not be at the cost of grain yield. Therefore, a correlation study was conducted between grain yield per plant and $\mathrm{Fe}$ as well as $\mathrm{Zn}$ content. A non significant correlation was observed both for $\mathrm{Fe}$ and $\mathrm{Zn}$ content with grain yield per plant at phenotypic as well as genotypic level in the two environments. This is supported by the studies of Gupta et al. (2009), Rai et al. (2012) and Kanatti et al. (2014). Studies have also observed significant but weak to moderate negative correlation between Fe and grain yield (Kanatti et al., 2014; Rai et al., 2012, 2013). Similarly, significant and weak negative correlation was observed between $\mathrm{Zn}$ and grain yield (Kanatti et al., 2014). Traits namely, plant height, ear length, ear diameter, 1000 grain weight and dry fodder yield per plant exhibited significant positive correlation at both the levels with grain yield per plant. The positive correlation of grain yield per plant with these characters implies that improving one or more of these traits could result in higher grain yield for pearl millet.

\subsection{Morphological cluster analysis}

Morphological characters and $\mathrm{Fe}$ as well as $\mathrm{Zn}$ content were used for cluster analysis to estimate genetic divergence between genotypes with an aim to improve yield along with quality. The cluster analysis is helpful in selection of genotypes for their further use in the hybrid breeding programme and creation of greater variability to broaden genetic base. All the 36 genotypes were clustered into 5 clusters at a Standard Euclidean Square distance of 15 based on Ward's Minimum Variance method (Figure 1a and 1b). This suggests that significant diversity is present in the experimental material for the characters studied including nutritional parameters. Similar level of diversity for morphological traits was observed by Ramya et al. (2017) and Abdulhakeem et al. (2019) in pearl millet genotypes. The members of clusters in two environments were nearly same with minor differences (Table 4). According to the cluster pattern of NS, cluster 1 and 3 were largest consisting of 11 genotypes each followed by cluster 4 ( 7 genotypes) and cluster 5 ( 5 genotypes). Smallest cluster was 2 with only 2 genotypes. Whereas cluster pattern of LS had cluster 2 as the largest with 11 genotypes followed by cluster 1 ( 9 genotypes), cluster 5 ( 7 genotypes), cluster 3 (5 genotypes) and cluster 4 (4 genotypes). The intra and inter cluster distances for the two environments are given in Table 5. Range for diversity within cluster varied from 2.75 to 4.43 in NS and 2.36 to 3.97 in LS. A maximum difference among the genotypes within the same cluster was shown by cluster 2 (4.43) and cluster 3 (3.97) indicating high divergence among the genotypes of the clusters, whereas lowest was exhibited by cluster 4 (2.75) and cluster 1 (2.36) in NS and LS respectively. Cluster 2 and 3 had maximum inter cluster distance of 6.32 in NS whereas cluster 1 and 3 showed a value 6.07 in LS. 


\section{WARD'S MINIMUM VARIANCE DENDROGRAM}

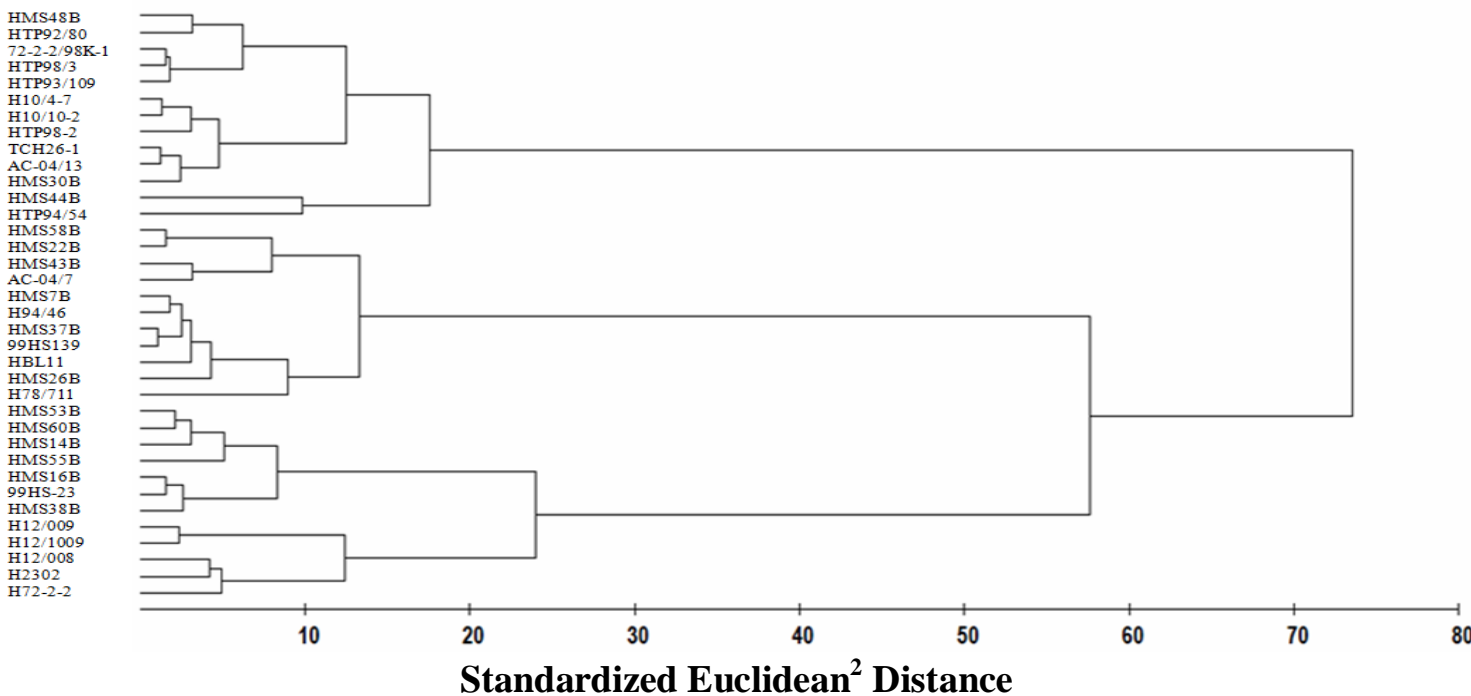

Figure 1a Standardized Euclidean ${ }^{2}$ distance based dendrogram of thirty-six pearl millet genotypes under normal-sown conditions

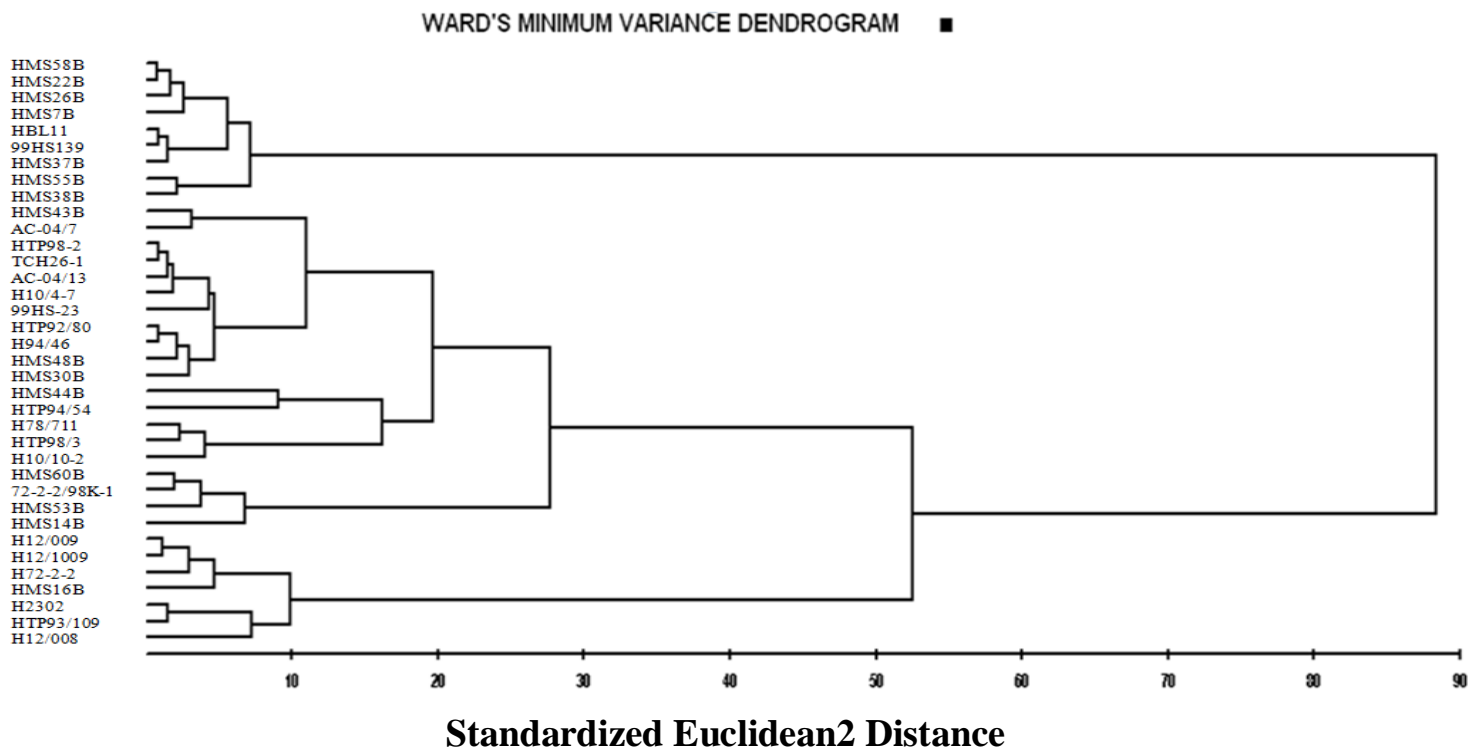

Figure 1b Standardized Euclidean ${ }^{2}$ distance based dendrogram of thirty-six pearl millet genotypes under late-sown conditions

Useful recombinants can be generated for hybridization by selecting lines from these clusters. Minimum inter cluster distance was observed between cluster 1 and 4 (3.95) and between cluster 2 and 4 (3.79) in NS and LS respectively. Thus crossing of genotypes from these clusters may be avoided as it may not produce a high amount of heterotic expression in $F_{1}$ and broad range of variability in $\mathrm{F}_{2}$ segregating population.
There is a considerable difference among all the clusters as revealed by cluster means for the 9 characters studied. Cluster wise mean and over all cluster mean for the characters are presented in Table 6. Cluster mean performance for grain yield and other contributing characters was highest for cluster 1 and cluster 3 in NS and LS respectively while moderately high for cluster 5 in both the environments. Also, from the present data, it

Journal of Experimental Biology and Agricultural Sciences http://www.jebas.org 
Table 4 Clustering of thirty-six pearl millet genotypes based on different morphological and biochemical parameters

\begin{tabular}{|c|c|c|c|}
\hline Cluster & & Number of genotypes & Name of genotypes \\
\hline \multirow{2}{*}{ Cluster 1} & NS & 11 & $\begin{array}{l}\text { HMS 48B, HMS 30B, 72-2-2/98k-1, HTP 93/109, HTP 98-2, H 10/4-7, H 10/10-2, HTP } \\
\text { 98/3, HTP 92/80, TCH 26-1 and AC-04/13 }\end{array}$ \\
\hline & LS & 9 & $\begin{array}{l}\text { HMS 58B, HMS 55B, HMS 7B, HMS 22B, HMS 38B, HMS 37B, HMS 26B, HBL } 11 \text { and } \\
99 \text { HS } 139\end{array}$ \\
\hline \multirow{2}{*}{ Cluster 2} & NS & 2 & HMS 44B and HTP 94/54 \\
\hline & LS & 11 & $\begin{array}{l}\text { HMS 48B , HMS 43B, HMS 30B, AC-04/7, HTP 98-2, H 10/4-7, HTP 92/80, TCH 26-1, H } \\
94 / 46 \text {, AC-04/13 and } 99 \text { HS-23 }\end{array}$ \\
\hline \multirow{2}{*}{ Cluster 3} & NS & 11 & $\begin{array}{l}\text { HMS 58B, HMS 43B, HMS 7B, HMS 22B, HMS 37B, HMS 26B, AC-04/7, H 78/711, H } \\
\text { 94/46, HBL } 11 \text { and } 99 \text { HS } 139\end{array}$ \\
\hline & LS & 5 & HMS 44B, H 78/711, H 10/10-2, HTP 94/54 and HTP 98/3 \\
\hline \multirow{2}{*}{ Cluster 4} & NS & 7 & HMS 14B, HMS 53B, HMS 55B, HMS 60B, HMS 16B, HMS 38B and 99 HS-23 \\
\hline & LS & 4 & HMS 14B, HMS 53B, HMS 60B and 72-2-2/98K-1 \\
\hline \multirow{2}{*}{ Cluster 5} & NS & 5 & H 72-2-2, H 12/009, H 12/008, H 2302 and H 12/1009 \\
\hline & LS & 7 & HMS 16B, H 72-2-2, H 12/009, H 12/008, H 2302, HTP 93/109 and H 12/1009 \\
\hline
\end{tabular}

Table 5 Average Inter and Intra cluster distancesof five clusters based on Ward‘s Minimum Variance method

\begin{tabular}{|c|c|c|c|c|c|c|c|c|c|c|}
\hline & \multicolumn{2}{|c|}{ Cluster 1} & \multicolumn{2}{|c|}{ Cluster 2} & \multicolumn{2}{|c|}{ Cluster 3} & \multicolumn{2}{|c|}{ Cluster 4} & \multicolumn{2}{|c|}{ Cluster 5} \\
\hline & NS & LS & NS & LS & NS & LS & NS & LS & NS & LS \\
\hline Cluster 1 & 2.76 & 2.36 & 4.33 & 3.98 & 4.33 & 6.07 & 3.95 & 4.18 & 4.84 & 5.29 \\
\hline Cluster 2 & & & 4.43 & 2.58 & 6.32 & 3.88 & 5.54 & 3.79 & 6.15 & 4.30 \\
\hline Cluster 3 & & & & & 3.09 & 3.97 & 4.03 & 4.79 & 5.09 & 4.97 \\
\hline Cluster 4 & & & & & & & 2.75 & 2.88 & 4.03 & 4.41 \\
\hline Cluster 5 & & & & & & & & & 3.46 & 3.02 \\
\hline
\end{tabular}

Diagonal values are intra cluster distances

Table 6 Mean values of various clusters for different morphological and biochemical parameters

\begin{tabular}{|c|c|c|c|c|c|c|c|c|c|c|c|c|c|c|c|c|c|c|}
\hline & \multicolumn{2}{|c|}{ DT50\% } & \multicolumn{2}{|c|}{$\mathrm{PH}(\mathrm{cm})$} & \multicolumn{2}{|c|}{$\mathrm{EL}(\mathrm{cm})$} & \multicolumn{2}{|c|}{$\mathrm{ED}(\mathrm{cm})$} & \multicolumn{2}{|c|}{$1000 \mathrm{GW}(\mathrm{g})$} & \multicolumn{2}{|c|}{ GY/P (g) } & \multicolumn{2}{|c|}{ DFY/P (g) } & \multicolumn{2}{|c|}{$\mathrm{Fe}(\mathrm{ppm})$} & \multicolumn{2}{|c|}{$\mathrm{Zn}(\mathrm{ppm})$} \\
\hline & NS & LS & NS & LS & NS & LS & NS & LS & NS & LS & NS & LS & NS & LS & NS & LS & NS & LS \\
\hline Cluster 1 & 51.18 & 52.72 & 169.53 & 97.68 & 22.17 & 15.63 & 2.29 & 1.76 & 8.32 & 5.68 & 27.41 & 7.58 & 71.15 & 21.73 & 43.32 & 45.56 & 33.23 & 34.61 \\
\hline Cluster 2 & 58.50 & 50.36 & 188.00 & 138.22 & 26.15 & 17.85 & 2.47 & 2.06 & 11.73 & 7.44 & 26.41 & 17.12 & 93.90 & 49.00 & 43.50 & 47.36 & 33.25 & 33.09 \\
\hline Cluster 3 & 54.23 & 47.60 & 136.60 & 163.00 & 18.17 & 22.160 & 1.88 & 2.30 & 6.44 & 9.46 & 24.06 & 19.66 & 39.01 & 57.18 & 41.95 & 50.80 & 33.95 & 38.20 \\
\hline Cluster 4 & 54.50 & 50.00 & 106.46 & 97.87 & 19.30 & 20.87 & 2.34 & 2.34 & 7.80 & 6.30 & 23.12 & 12.49 & 54.62 & 36.31 & 68.14 & 77.87 & 46.93 & 45.37 \\
\hline Cluster 5 & 50.90 & 48.57 & 150.00 & 137.79 & 16.52 & 16.75 & 2.09 & 1.86 & 9.15 & 8.90 & 18.03 & 15.11 & 74.10 & 55.18 & 85.30 & 89.64 & 64.00 & 66.93 \\
\hline
\end{tabular}
per plant, $\mathrm{DFY} / \mathrm{P}=$ Dry fodder yield per plant, $\mathrm{Fe}=$ Iron and $\mathrm{Zn}=\mathrm{Zinc}$

is evident that the mean value of $\mathrm{Fe}$ and $\mathrm{Zn}$ is highest in cluster 5 (85.30 ppm Fe and $64.00 \mathrm{ppm} \mathrm{Zn} \mathrm{in} \mathrm{NS} \mathrm{and} 89.64 \mathrm{ppm} \mathrm{Fe}$ and $66.93 \mathrm{ppm} \mathrm{Zn}$ in LS). This signifies that the cluster 5 is composed of high $\mathrm{Fe}$ and $\mathrm{Zn}$ genotypes consistent in two environments. Exploitation of heterosis can only be done by utilizing parents with maximum genetic divergence. This increases spectrum of variability in the segregating generation and a more pronounced heterotic effect can be achieved. Therefore, genotypes from cluster 5 will serve as potential parents for enhancing grain $\mathrm{Fe}$ and $\mathrm{Zn}$ content with simultaneous improvement in yield and its associated characters. Also, days to $50 \%$ flowering mean is less in this cluster that means hybrids which can escape terminal drought 
can be produced by crossing genotypes belonging to this cluster.

\subsection{Molecular marker analysis}

Sixty-four primer pairs selected out of 71 primer pairs amplified a total of 461 alleles. The number of alleles per locus varied from 2 (ICMP 3016, ICMP 3018, XCUMP 0017, XCUMP 0019 and PSMP 20176) to 27 (PSMP 2008) with a mean of 7.20 alleles per locus (Table 7). This value is much higher than the value of mean alleles per locus reported earlier i.e. 5.7 (Budak et al., 2003), 3.07 (Sumanth et al., 2013) and 3.0 (Singh et al., 2013) but lesser than the value 16.4 as obtained by Stich et al. (2010). The value obtained is comparable with value 6.26 (Kapila et al., 2008) and 8.1 (Nepolean et al., 2012). Fourteen primers amplified alleles in range of 11 to 16 . The highest number of alleles (27) was obtained using primer PSMP 2008 with a dinucleotide type of repeat $\left[(\mathrm{GT})_{37}\right]$. A value more than
27 number of alleles has also been reported at individual loci by Saghai-Maroof et al. (1994) (37 alleles in barley) and Rongwen et al. (1995) (26 alleles in soybean) suggesting high levels of polymorphism in plant SSRs. Primers Xpsmp2070 and Xpsmp 2218 have also been reported to amplify more than 20 alleles by Nepolean et al. (2012). Gupta et al. (2015) observed up to 40 alleles amplified by primer Xpsmp 2218 while 23 to 40 alleles per locus were amplified by primers Xpsmp 2068, Xpsmp 2079 and Xpsmp 2218. Polymorphic Information Content (PIC) value in present study ranged from 0.14 (PSMP 2227) to 0.95 (PSMP 2008 ) with an average of 0.68 which is near to value 0.77 as observed by Bashir et al. (2015) but higher than 0.58 (Kapila et al., 2008; Nepolean et al., 2012) and 0.44 (Budak et al., 2003; Singh et al., 2013). Primer PSMP 2008 with highest PIC was found to be highly informative of all the primers surveyed. Figure 2 shows the allelic polymorphism among 36 pearl millet genotypes at PSMP 2201 locus.

Table 7 Amplification results of 64 SSR primers

\begin{tabular}{|c|c|c|c|c|c|c|}
\hline S. No. & SSR locus & $\begin{array}{c}\text { Linkage } \\
\text { group (LG) }\end{array}$ & SSR motif & $\begin{array}{l}\text { Amp. Range } \\
\text { (bp) }\end{array}$ & Allele No. & PIC (B- \& R-line) \\
\hline 1 & PSMP 2008 & 5 & $(\mathrm{GT})_{37}$ & $120-1000$ & 27 & $0.95(0.93 ; 0.94)$ \\
\hline 2 & PSMP 2027 & 7 & $(\mathrm{GT})_{31}$ & $238-410$ & 11 & $0.84(0.79 ; 0.85)$ \\
\hline 3 & PSMP 20 & NA & NA & $150-200$ & 7 & $0.78(0.79 ; 0.76)$ \\
\hline 4 & PSMP 2059 & 2 & $(\mathrm{AC})_{11}$ & $115-125$ & 6 & $0.78(0.82 ; 0.74)$ \\
\hline 5 & PSMP 2084 & 4 & $(\mathrm{AC})_{42}$ & $228-1000$ & 13 & $0.89(0.80 ; 0.90)$ \\
\hline 6 & PSMP 2087 & 7 & $(\mathrm{AC})_{10}$ & $120-140$ & 5 & $0.72(0.67 ; 0.74)$ \\
\hline 7 & PSMP 2090 & 1 & $(\mathrm{CT})_{12}$ & $150-330$ & 7 & $0.82(0.67 ; 0.75)$ \\
\hline 8 & PSMP 2201 & 2 & $(\mathrm{GT})_{6}$ & $368-505$ & 11 & $0.81(0.73 ; 0.84)$ \\
\hline 9 & PSMP 2224 & 7 & $(\mathrm{TG})_{10}$ & $130-185$ & 7 & $0.78(0.77 ; 0.79)$ \\
\hline 10 & PSMP 2227 & 3 & $(\mathrm{GT})_{7}$ & $195-220$ & 3 & $0.14(0.12 ; 0.16)$ \\
\hline 11 & PSMP 2229 & 5,7 & $(\mathrm{GT})_{5}$ & $220-600$ & 4 & $0.42(0.39 ; 0.44)$ \\
\hline 12 & PSMP 2232 & 1,2 & $(\mathrm{TG})_{8}$ & $230-380$ & 6 & $0.75(0.74 ; 0.74)$ \\
\hline 13 & PSMP 2233 & 5 & $(\mathrm{TG})_{9}$ & $250-900$ & 8 & $0.81(0.73 ; 0.83)$ \\
\hline 14 & PSMP 2237 & 2 & $(\mathrm{GT})_{8}$ & $205-500$ & 14 & $0.89(0.87 ; 0.86)$ \\
\hline 15 & PSMP 2246 & 1 & $(\mathrm{TG})_{7}$ & $245-390$ & 5 & $0.47(0.31 ; 0.53)$ \\
\hline 16 & PSMP 22 & NA & NA & $160-220$ & 5 & $0.70(0.73 ; 0.67)$ \\
\hline 17 & PSMP 2263 & 7 & $(\mathrm{AG})_{33}$ & $200-260$ & 7 & $0.82(0.63 ; 0.79)$ \\
\hline 18 & PSMP 2270 & 6 & $(\mathrm{GA})_{26}$ & $150-180$ & 7 & $0.61(0.55 ; 0.64)$ \\
\hline 19 & PSMP 2271 & 7 & $(\mathrm{GA})_{11}$ & $180-240$ & 5 & $0.67(0.39 ; 0.70)$ \\
\hline 20 & PSMP 2273 & 1 & $(\mathrm{GA})_{12}$ & $155-240$ & 6 & $0.65(0.44 ; 0.59)$ \\
\hline 21 & PSMP 2274 & $5,7 \mathrm{~b}$ & $(\mathrm{GA})_{13}$ & $230-350$ & 9 & $0.74(0.66 ; 0.78)$ \\
\hline 22 & ICMP 3016 & 6 & $(\mathrm{CA})_{17}$ & $550-600$ & 2 & $0.50(0.50 ; 0.50)$ \\
\hline 23 & ICMP 3017 & 1 & $(\mathrm{CAG})_{7}$ & $178-240$ & 11 & $0.84(0.70 ; 0.84)$ \\
\hline 24 & ICMP 3018 & NA & $(\mathrm{CATG})_{4}$ & $210-225$ & 4 & $0.71(0.68 ; 0.72)$ \\
\hline
\end{tabular}

Journal of Experimental Biology and Agricultural Sciences http://www.jebas.org 


\begin{tabular}{|c|c|c|c|c|c|c|}
\hline S. No. & SSR locus & $\begin{array}{c}\text { Linkage } \\
\text { group (LG) }\end{array}$ & SSR motif & $\begin{array}{l}\text { Amp. Range } \\
\text { (bp) }\end{array}$ & Allele No. & PIC (B- \& R-line) \\
\hline 25 & ICMP 3019 & NA & $(\mathrm{CGTA})_{4}$ & $190-210$ & 2 & $0.49(0.44 ; 0.50)$ \\
\hline 26 & ICMP 3020 & NA & $(\mathrm{CGTG})_{5}$ & $195-200$ & 3 & $0.19(0.38 ; 0.00)$ \\
\hline 27 & ICMP 3029 & 4 & $(\mathrm{GCA})_{6}(\mathrm{GCA})_{5}$ & $216-250$ & 8 & $0.80(0.76 ; 0.79)$ \\
\hline 28 & ICMP 3050 & 6 & $(\mathrm{TA})_{8}$ & $210-260$ & 5 & $0.50(0.12 ; 0.61)$ \\
\hline 29 & ICMP 3056 & 2 & $(\mathrm{TGG})_{5}$ & $135-155$ & 3 & $0.48(0.39 ; 0.53)$ \\
\hline 30 & ICMP 3088 & 1 & $(\mathrm{TCC})_{8}(\mathrm{TCTA})_{4}$ & $145-1000$ & 15 & $0.86(0.87 ; 0.74)$ \\
\hline 31 & ICMP 10 & NA & NA & $300-1100$ & 16 & $0.82(0.78 ; 0.83)$ \\
\hline 32 & XCUMP 005 & NA & $(\mathrm{CTG})_{9}$ & $148-195$ & 9 & $0.76(0.52 ; 0.84)$ \\
\hline 33 & XCUMP 006 & NA & $(\text { TATG })_{9}$ & $152-900$ & 11 & $0.86(0.85 ; 0.86)$ \\
\hline 34 & XCUMP 009 & NA & $(\mathrm{CTC})_{6}$ & $152-160$ & 5 & $0.63(0.59 ; 0.65)$ \\
\hline 35 & XCUMP 0016 & NA & $(\mathrm{CT})_{9}$ & $190-1000$ & 14 & $0.85(0.85 ; 0.84)$ \\
\hline 36 & XCUMP 0017 & & $(\mathrm{AAG})_{7}$ & $105-110$ & 2 & $0.18(0.00 ; 0.27)$ \\
\hline 37 & XCUMP 0018 & NA & $(\mathrm{GCA})_{7}$ & $220-800$ & 6 & $0.80(0.73 ; 0.73)$ \\
\hline 38 & XCUMP 0019 & NA & $(\mathrm{AGCG})_{5}$ & $220-300$ & 2 & $0.47(0.48 ; 0.47)$ \\
\hline 39 & CTM 8 & 7 & $(\mathrm{CT})_{8}(\mathrm{CT})_{11}$ & $240-400$ & 5 & $0.76(0.76 ; 0.77)$ \\
\hline 40 & СТM 10 & 3 & $(\mathrm{CT})_{22}$ & $160-230$ & 12 & $0.88(0.82 ; 0.89)$ \\
\hline 41 & СТM 21 & 2 & $(\mathrm{CT})_{24}$ & $180-300$ & 8 & $0.82(0.76 ; 0.80)$ \\
\hline 42 & CTM 25 & 5 & $(\mathrm{CT})_{34}$ & $230-900$ & 9 & $0.79(0.78 ; 0.79)$ \\
\hline 43 & СТM 26 & NA & $(\mathrm{CT})_{10}$ & $250-300$ & 6 & $0.74(0.69 ; 0.76)$ \\
\hline 44 & СТМ 27 & 1 & $(\mathrm{CT})_{71}$ & $320-700$ & 8 & $0.80(0.72 ; 0.76)$ \\
\hline 45 & CTM 55 & NA & $(\mathrm{CT})_{25}$ & $710-800$ & 4 & $0.74(0.55 ; 0.69)$ \\
\hline 46 & СТM 58 & NA & $(\mathrm{CT})_{24}$ & $280-900$ & 12 & $0.88(0.81 ; 0.89)$ \\
\hline 47 & СТМ 59 & NA & $(\mathrm{CT})_{11}$ & $261-265$ & 3 & $0.59(0.64 ; 0.53)$ \\
\hline 48 & СТM 60 & NA & $(\mathrm{CT})_{23}$ & $120-950$ & 3 & $0.62(0.58 ; 0.64)$ \\
\hline 49 & PGIRD 46 & NA & $(\mathrm{CTC})_{6}$ & $90-98$ & 4 & $0.48(0.34 ; 0.53)$ \\
\hline 50 & PGIRD 49 & NA & $(\mathrm{CGG})_{6}$ & $190-400$ & 12 & $0.84(0.81 ; 0.83)$ \\
\hline 51 & PGIRD 50 & NA & $(\mathrm{TGT})_{6}$ & $150-225$ & 7 & $0.82(0.81 ; 0.81)$ \\
\hline 52 & PGIRD 54 & NA & $(\mathrm{GT})_{5}$ & $114-174$ & 11 & $0.85(0.85 ; 0.85)$ \\
\hline 53 & PSMP 2001 & 5 & $(\mathrm{CT})_{8}(\mathrm{CA})_{48}$ & $205-380$ & 7 & $0.76(0.74 ; 0.73)$ \\
\hline 54 & PSMP 2030 & 1 & $(\mathrm{CA})_{11}(\mathrm{GA})_{10}$ & $118-500$ & 12 & $0.75(0.73 ; 0.75)$ \\
\hline 55 & PSMP 2043 & NA & $(\mathrm{CA})_{13}(\mathrm{GA})_{6}$ & $190-750$ & 5 & $0.68(0.69 ; 0.64)$ \\
\hline 56 & PSMP 2076 & 4 & $(\mathrm{AC})_{15}$ & $150-170$ & 2 & $0.48(0.30 ; 0.49)$ \\
\hline 57 & PSMP 2080 & NA & $(\mathrm{AC})_{14}$ & $180-240$ & 7 & $0.79(0.73 ; 0.79)$ \\
\hline 58 & PSMP 2085 & 5 & (AC) 11 & $170-240$ & 6 & $0.71(0.57 ; 0.71)$ \\
\hline 59 & PSMP 2208 & 5 & (GT) 10 & $250-380$ & 4 & $0.43(0.38 ; 0.47)$ \\
\hline 60 & PSMP 2248 & 6 & $(\mathrm{TG}) 10$ & $160-220$ & 4 & $0.63(0.64 ; 0.61)$ \\
\hline 61 & PSMP 2249 & 3 & $(\mathrm{GT}) 7$ & $130-240$ & 6 & $0.76(0.75 ; 0.73)$ \\
\hline 62 & PSMP 2267 & 3 & (GA) 16 & $210-235$ & 3 & $0.14(0.12 ; 0.16)$ \\
\hline 63 & PSMP 2275 & 6 & $(\mathrm{AAG})$ & $260-400$ & 6 & $0.68(0.75 ; 0.60)$ \\
\hline 64 & ICMP 3002 & 6 & NA & $220-350$ & 4 & $0.61(0.54 ; 0.65)$ \\
\hline
\end{tabular}

Journal of Experimental Biology and Agricultural Sciences http://www.jebas.org 


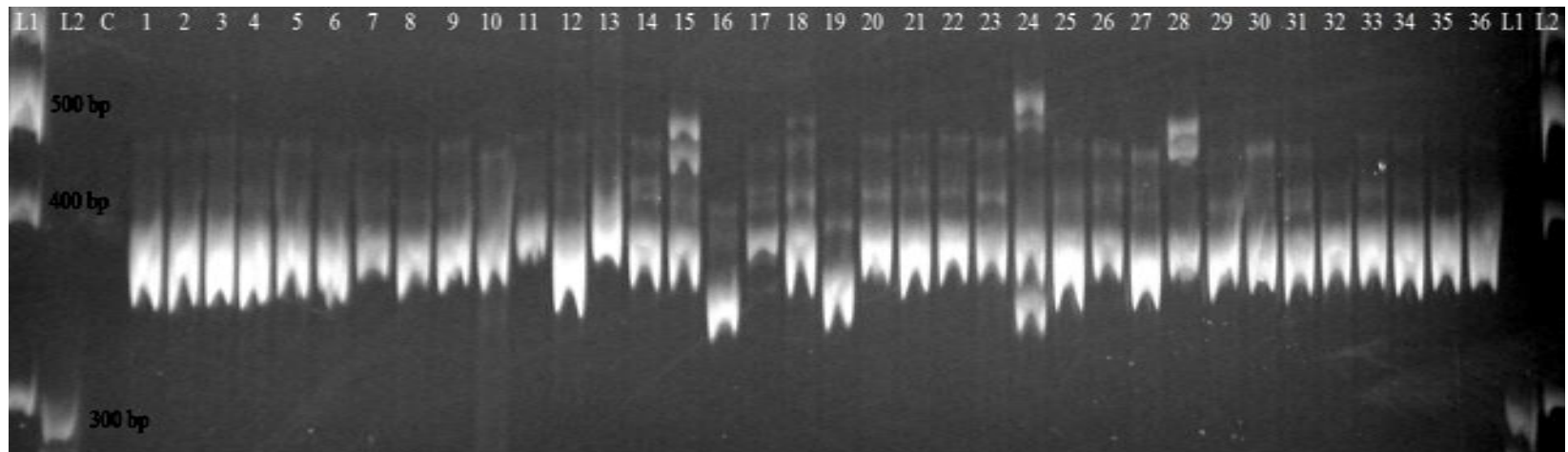

Figure 2 Ethidium bromide stained 6\% polyacrylamide gel showing allelic polymorphism among 36 pearl millet genotypes at PSMP 2201 locu s. Lane $\mathrm{L}_{1}=100 \mathrm{bp}$ ladder, $\mathrm{L}_{2}=20$ bp ladder, $\mathrm{C}=$ negative control and 1 to 36 represents HMS 48B, HMS 14B, HMS 58B, HMS 53B, HMS 55B, HMS 43B, HMS 60B, HMS 7B, HMS 44B, HMS 22B, HMS 16B, HMS 38B, HMS 37B, HMS 26B, HMS 30B, H 72-2-2, H 12/009, H 12/008, AC04/7, H 2302, 72-2-2/98K-1, HTP 93/109, HTP 98-2, H 78/711, H 10/4-7, H 10/10-2, HTP 94/54, HTP 98/3, HTP 92/80, TCH 26-1, H 94/46, HBL 11, AC-04/13, H 12/1009, 99 HS 139 and 99 HS-23

SSR loci XCUMP 0017 and ICMP 3020 were monomorphic for $\mathrm{B}$ - and R-lines, respectively. The PIC value for B-lines varied from 0.12 (PSMP 2227 and PSMP 2267) to 0.93 (PSMP 2008) with an average of 0.63 whereas for R-lines it ranged from 0.16 (PSMP 2227 and PSMP 2267) to 0.94 (PSMP 2008) and an average of 0.68 (Table 7). In both kinds of lines same SSR loci are exhibiting lowest and highest PIC. Nepolean et al. (2012) have reported average PIC values for B- and R-lines as 0.46 and 0.58 , respectively and Gupta et al. (2015) observed values 0.56 and 0.70 for B- and R-lines, respectively. Higher numbers of alleles were revealed by R-lines (407) than B-lines (357). Mean alleles per locus were 5.58 (B-lines) and 6.36 (R-lines). More number of alleles amplified in R-lines can be credited to the broader genetic base used in the development of these lines and the differences in sample size (21 R-lines vs. 15 B-lines). Previous studies have also reported more diversity in R-lines as compared to B-lines. Nepolean et al. (2012) observed occurrence of 284 alleles in 115 R-lines and 214 alleles in 98 B-lines using 38 SSRs. Similarly, Gupta et al. (2015) reported 329 alleles in 193 R-lines and 237 alleles in 186 B-lines using a set of highly polymorphic 28 SSRs.

The high number of alleles and PIC value obtained could be credited to polyacrylamide gel having higher resolving power than agarose gel electrophoresis and to a high number (i.e. $67 \%$ of total primers amplified) of dinucleotide SSR primers used on a small number of samples in the study. The overall size of PCR amplified products ranged from $90 \mathrm{bp}$ (PGIRD 46) to $1100 \mathrm{bp}$ (ICMP 10). The molecular size difference between the smallest and the largest allele at a SSR locus varied from 4 bp (CTM 59) to 880 bp (PSMP 2008). More than two alleles also called Surnumary bands were observed in this study which can be explained as duplication of some loci as also discussed in earlier studies or EST belonging to multi gene families (Devos et al., 2000; Budak et al., 2003; Mariac et al., 2006). As the genotypes used were inbred lines, still occurrence of more than one allele at loci can be explained on the basis that pearl millet is a highly out crossing crop with higher chances of contamination from foreign pollen and this residual heterozygosity at loci demands more inbreeding along with maintenance breeding. This also signifies the importance of molecular markers in elucidating the heterozygosity which cannot be determined solely by morphological data.

A significant positive correlation was observed among number of alleles, PIC and number of repeats in the SSR motifs (Table 8). Highly significant positive correlation between number of alleles and PIC ( $\mathrm{r}=0.69, \mathrm{p}=0.01)$ implies that alleles can be indirectly used to assess PIC. Similarly, significant positive correlation values for number of repeats in SSR motifs with number of alleles $(\mathrm{r}=0.30, \mathrm{p}=0.05)$ and PIC $(\mathrm{r}=0.30, \mathrm{p}=0.05)$ signifies selection of repeats while taking in consideration the size of repeats for such studies. Similar associations have been reported by other studies as well (Huang et al., 2002; Ni et al., 2002; Kapila et al., 2008; Sumanth et al., 2013). However, according to Budak et al. (2003) the degree of polymorphism did not correlate with the number of repeats in the microsatellites but were stated to be correlated with the mutation rate.

Few of the studies have conducted genetic diversity evaluation across linkage groups. Genetic diversity analysis on the whole genome basis was done by using molecular markers from all 7

Table 8 Correlation between PIC, Number of alleles and Number of repeats

\begin{tabular}{|cccc|}
\hline PIC & 1 & $0.695^{* *}$ & $0.303^{*}$ \\
\hline $\begin{array}{c}\text { Number of } \\
\text { alleles }\end{array}$ & $0.695^{* *}$ & 1 & $0.296^{*}$ \\
\hline $\begin{array}{c}\text { Number of } \\
\text { repeats }\end{array}$ & $0.303^{*}$ & $0.296^{*}$ & 1 \\
\hline
\end{tabular}

*,** Significant at $\mathrm{P}=0.05$ and $\mathrm{P}=0.01$ levels respectively 


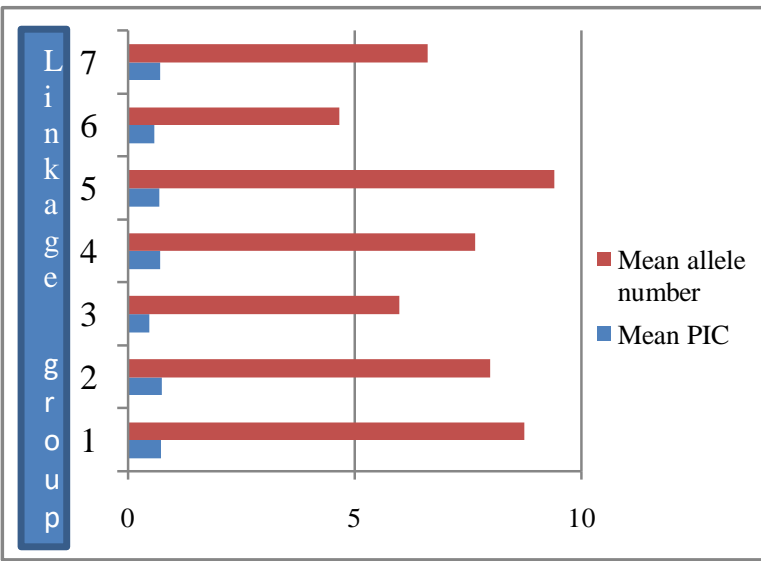

Figure 3 Mean allele number and PIC of different linkage groups

linkage groups (LG). This provided difference existing in the genetic makeup throughout the genome. In the present study, mean PIC varied across the linkage groups from 0.48 (LG 3) to 0.76 (LG 2) (Figure 3). Kapila et al. (2008) observed lowest PIC value for LG 6 (0.239), concluding evolutionary more dynamic nature of this linkage group. In present study, however lowest PIC value is observed for LG 3 (0.48) and LG 6 showed a moderate value of 0.59 explained on the basis that number of markers belonging to LG 3 used were low (4 markers). LG 2 and LG 1 displaying high values of PIC and mean allele number suggests presence of a high level of genetic variation at these linkage groups.
Presence of unique alleles (i.e. exclusively present in a genotype) was also observed in this study (Table 9). Out of 461 alleles, 25 alleles were unique to a genotype. A total of 18 primers amplified these genotype-specific alleles. ICMP 3088 amplified maximum number of unique alleles (4) in 3 genotypes. Amplification of unique alleles only in B- and R-lines was by 9 and 7 primers respectively, whereas 2 primers amplified unique bands in both the lines. Out of 36 genotypes, 15 showed presence of unique alleles. Maximum unique alleles (10) were observed in HMS $30 \mathrm{~B}$ genotype with maximum number of primers (7) contributing these alleles to this genotype. Fifteen alleles were unique to $6 \mathrm{~B}$-lines and 10 alleles were unique to $9 \mathrm{R}$-lines. A significant number of unique alleles in both B- and R-lines, suggest that these lines have been derived from diverse genetic base. Nepolean et al. (2012) observed few unique alleles (1 to 3) in $14 \mathrm{~B}$ - and $30 \mathrm{R}$-lines whereas Gupta et al. (2015) found genotype specific alleles in 15 B- and 37 R-lines. The unique allele occurrence can be useful in characterizing the genotype, analysis of genetic purity and distinguishing them from each other in case of any discrepancy. These SSR alleles, along with distinctness, uniformity and stability (DUS) characterization can be used as genetic tags to help protect these lines from possible infringement. STS markers can also be generated from these unique bands easily. Such markers will then serve to detect any alien introgression and be used as DNA fingerprints. Also, may be the presence of these line-specific alleles indicates their association with some distinct trait(s) of that particular line, which needs further research using more genotypes to determine their exact significance.

Table 9 List of genotypes and SSR primers exhibiting unique alleles presence

\begin{tabular}{|cllc|}
\hline S. No. & Genotype & Primers & No. of unique bands \\
\hline 1 & HMS 48B & ICMP 3088 & 1 \\
\hline 2 & HHMS 55B & PSMP 2237 & 1 \\
\hline 3 & HMS 43B & XCUMP 006 & 1 \\
\hline 4 & HMS 7B & XCUMP0018 & 1 \\
\hline 5 & HMS 26B & PGIRD 46 & 1 \\
\hline 6 & HMS 30B & PSMP 2246, PSMP 2273, ICMP 3020, ICMP 3088, XCUMP 0016, & 10 \\
\hline 7 & H 72-2-2 & ICMP 3050 & 1 \\
\hline 8 & H 12/009 & PSMP 2233 & 1 \\
\hline 9 & H 12/008 & PSMP 2008 & 1 \\
\hline 10 & AC-04/7 & PGIRD 46 & 1 \\
\hline 11 & HTP 98-2 & PSMP 2270 & 1 \\
\hline 12 & H 78/711 & PSMP 20 & 1 \\
\hline 13 & H 10/10-2 & PSMP 2270 & 1 \\
\hline 14 & HTP 92/80 & PSMP 2090, ICMP 3088 & 2 \\
\hline 15 & H 94/46 & ICMP 3056 & 1 \\
\hline
\end{tabular}

Journal of Experimental Biology and Agricultural Sciences

http://www.jebas.org 
Genetic relatedness of the 36 genotypes calculated ranged from 0.16 (HMS 16B and H 78/711; H 78/711 and H 12/1009) to 0.49 (HMS $16 \mathrm{~B}$ and HMS 38B) with average pair-wise similarity coefficient 0.28 (i.e. between B- and R-lines). In case of B-lines, genetic similarity estimate was highest between HMS 16B and HMS 38B (0.49) and lowest between HMS 55B and HMS 7B (0.19) with an average value for similarity coefficients 0.32 . Whereas for R-lines, the highest value (0.44) was observed between 72-2-2/98k-1 and 99 HS 139 and the lowest value (0.16) obtained between $\mathrm{H}$ 78/711 and H 12/1009 with an average 0.27. Average similarity coefficient of B-lines was higher in comparison to R-lines. For prediction of hybrid performance, this information available on genetic distances between the parental lines can be used. New recombinants of B- and $\mathrm{R}$-line can be developed by designing crosses of B-line X B-line and R-line X R-line with greater genetic distance, making use of substantial diversity detected among them.

UPGMA dendrogram formed using NTSYS-pc software explained much of similarity present among the genotypes (Figure 4). The extremes of the dendrogram were occupied by HMS 48B and HTP 93/109, with all other distributed in between. The genotypes clustered into 6 clusters at an arbitrary cut-off of 0.28 similarity coefficient on dendrogram. The $1^{\text {st }}$ cluster formed is the largest, consisting of 16 genotypes encompassing B-lines and R-lines followed by a out group HMS 37B. $2^{\text {nd }}$ and $3^{\text {rd }}$ clusters comprised of 6 genotypes each (B and R-lines in $2^{\text {nd }}$ cluster and R-lines in $3^{\text {rd }}$ cluster). $4^{\text {th }}$ cluster was made by 2 genotypes (B and R-lines). $5^{\text {th }}$ and $6^{\text {th }}$ cluster consisted of 2 genotypes each, which were R-lines followed by one out group genotype namely, HTP 93/109. The failure of HMS 37B to fall into any cluster states that it is diverse of all B-lines and can be used for the new male sterile line development programme. Among the R-lines, HTP 93/109 was highly diversified from all and can be used as a potential pollinator for the elite CMS lines.

Clustering was also performed by WinBoot software program. Similar clusters were obtained with minor variations after 2000 iterations (data not shown). Some clusters showed high bootstrap values whereas others had low values indicating their chances to fall into another cluster and requirement for more genome coverage by using more number of SSR loci. The validation of clustering pattern on the basis of Win Boot scores for different clusters have been previously performed in various studies pertaining to genetic diversity analysis in crops like rice (Joshi et al., 2000), blackgram (Souframanien \& Gopalakrishna, 2004), sorghum (Jaikishan et al., 2013) and green gram (Singh et al., 2014).

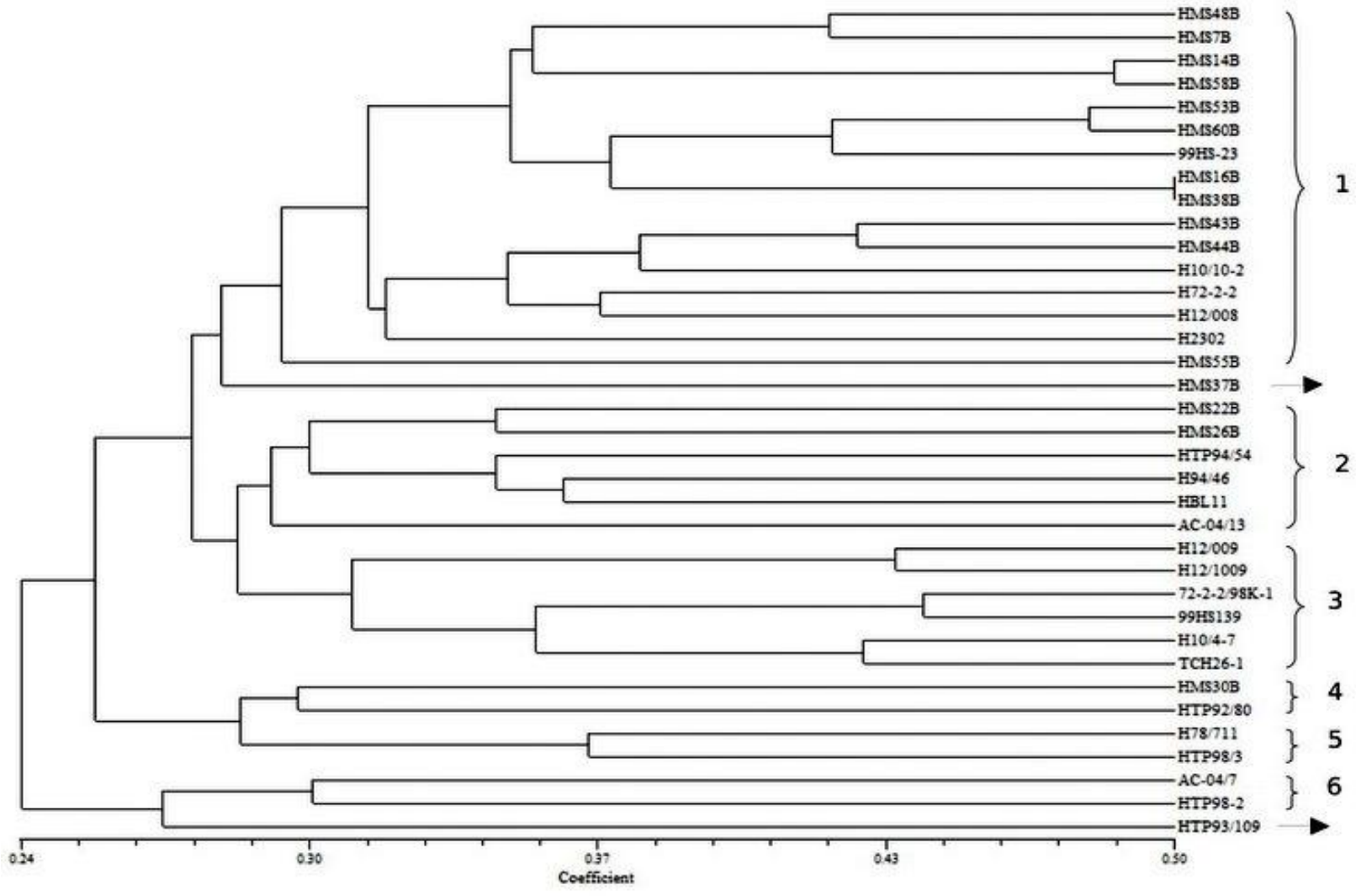

Figure 4 UPGMA dendrogram showing relationship among thirty-six pearl millet genotypes based on Jaccard similarity matrix data using 64 SSR primers

Journal of Experimental Biology and Agricultural Sciences http://www.jebas.org 
Furthermore, Jaccard similarity coefficient matrix was subjected to PCA for the three principal components. 2-D and 3-D plot were generated which clearly explain the relationship among the 36 pearl millet genotypes. The groupings in 2D (Figure 5) and 3-D scaling (Figure 6) followed the same pattern as depicted in the dendrogram with minor differences. PCA clearly grouped the lines in distinct clusters with some lines interspersed.

\section{Conclusion}

Present study with an aim to explore the diversity in the collection of pearl millet genotypes present at CCSHAU, Hisar used molecular markers along with biochemical and morphological characters. SSR markers proved to be effective in diversity assessment and in determining remnant heterozygosity at loci. Selection of contrasting parents for construction of mapping population in order to map QTL for $\mathrm{Fe}$ and $\mathrm{Zn}$ can be made using this genetic diversity study. The results of the analysis will be helpful in selection of best combination of parents for future breeding programmes to produce new improved hybrids having desired characters like high $\mathrm{Fe}$ and $\mathrm{Zn}$ as well as good yield and broadening of genetic variability.

\section{Conflict of Interest}

On behalf of all authors, the corresponding author states that there is no conflict of interest.

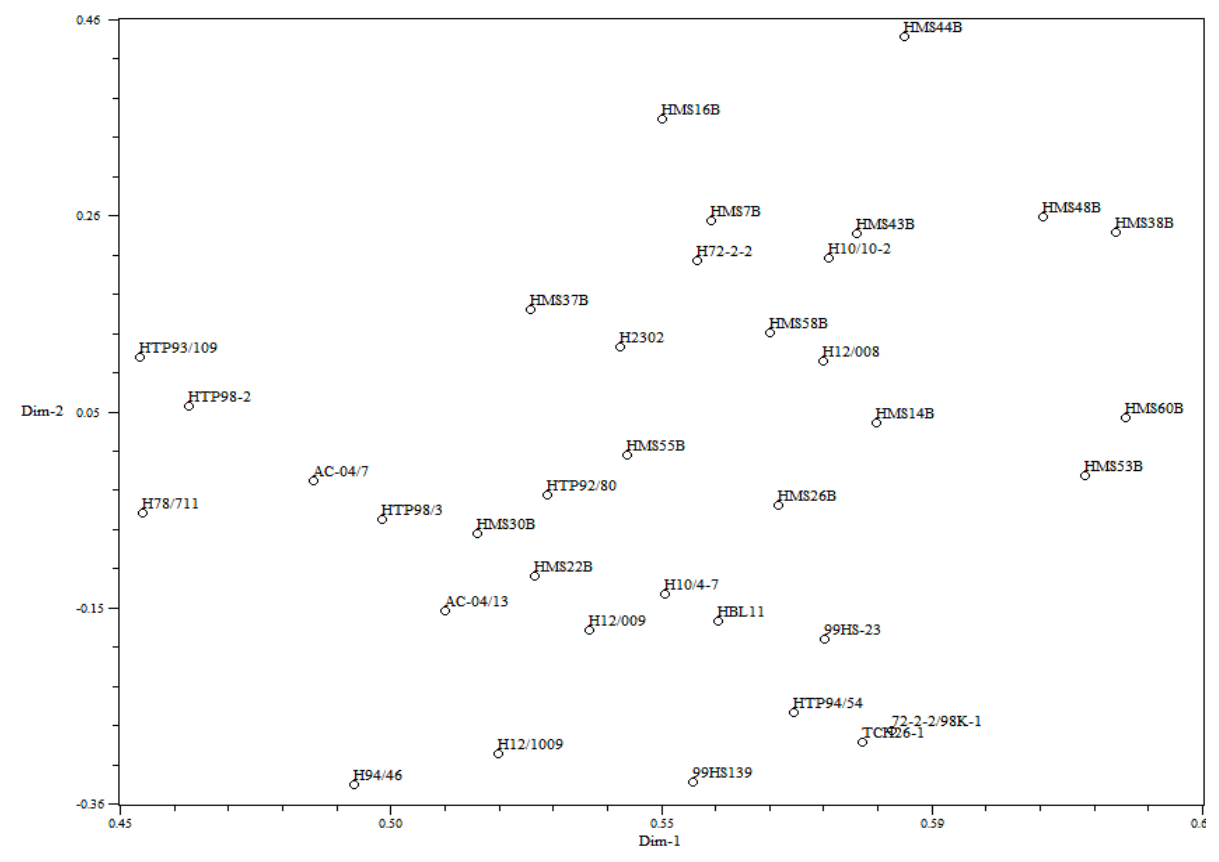

Figure 5 Two dimensional PCA (Principal Component Analysis) scaling of thirty-six pearl millet genotypes using similarity matrix data of 64 SSR primers

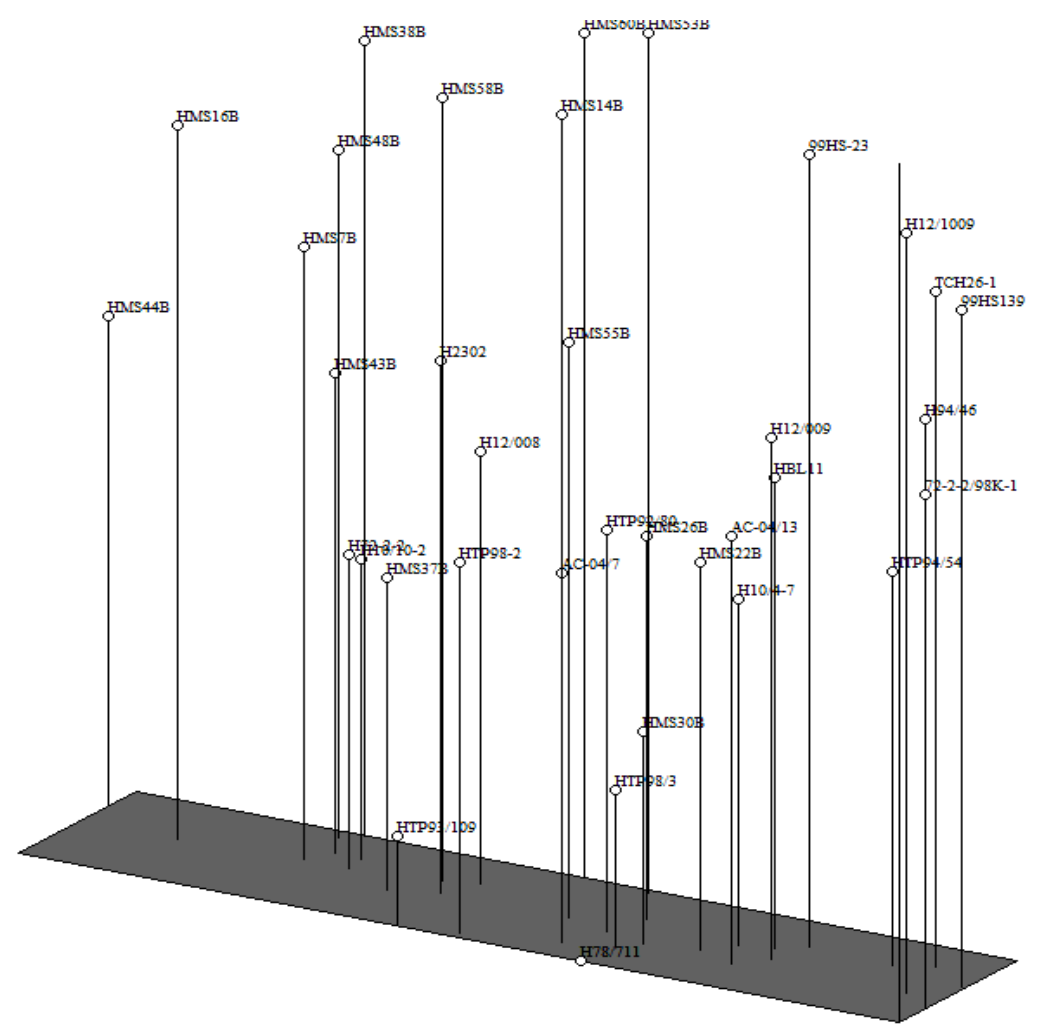

Figure 6 Three dimensional PCA (Principal component analysis) scaling of thirty-six pearl millet genotypes based on 64 SSR primers

Journal of Experimental Biology and Agricultural Sciences

http://www.jebas.org 


\section{Acknowledgements}

The authors gratefully acknowledge ICRISAT, Hyderabad for conducting $\mathrm{Fe}$ and $\mathrm{Zn}$ content analysis.

\section{Author Contributions}

$\mathrm{SS}^{1}$ SY RK conceived and designed the experiments.SS ${ }^{1}$ performed the experiments and wrote $1^{\text {st }}$ draft. RK carried out the statistical analysis of morphological traits. SS ${ }^{1}$ SY H NR involved in statistical analysis of molecular data. $\mathrm{SY} \mathrm{H} \mathrm{SS}^{3}$ reviewed the manuscript.

Informed consent: "Informed consent was obtained from all individual participants included in the study."

\section{References}

Abdulhakeem A, Ahmed FO, Omoniyi AM, Kayode OI, Yusuf DOA (2019) Genetic diversity studies for morphological traits in pearl millet (Pennisetum glaucum L.) landraces of Northern Nigeria. GSC Biological and Pharmaceutical Sciences 07: 60-70.

AICPMIP (2017) Project Coordinator's Review. Available from: www.aicpmip.res.in/pcr2017.pdf

Allouis S, Qi X, Lindup S, Gale MD, Devos KM (2001) Construction of a BAC library of pearl millet, Pennisetum glaucum. Theoretical and Applied Genetics 102:1200-1205.

Anandan A, Rajiv G, Eswaran R, Prakash M (2011) Genotypic variation and relationships between quality traits and trace elements in traditional and improved rice (Oryza sativa L.) genotypes. Journal of Food Science 76:H122-H130.

Bashir EMA, Abdelbagi MA, Adam MA, Melchinger AE, Parzies HK, Haussmann BIG (2014) Characterization of Sudanese pearl millet germplasm for agro-morphological traits and grain nutritional values. Plant Genetic Resources 12:35-47.

Bashir EMA, Abdelbagi MA, Adam MA, Mohamed ETI, Melchinger AE, Parzies HK, Haussmann BIG (2015) Genetic diversity of Sudanese pearl millet (Pennisetum glaucum (L.) R. $\mathrm{Br}$.) landraces as revealed by SSR markers, and relationship between genetic and agro-morphological diversity. Genetic Resources and Crop Evolution 62:579-591.

Bhattacharjee R, Khairwal IS, Bramel PJ, Reddy KN (2007) Establishment of a pearl millet [Pennisetum glaucum(L.) R. Br.] core collection based on geographical distribution and quantitative traits. Euphytica155:35-45.

Bhoite KD, Pardeshi SR, Mhaske BM, Wagh MP (2008) Study of genetic variability in pearl millet (Pennisetum glaucum L.). Agricultural Science Digest 28:115-117.
Bind H, Bharti B, Kumar S, Pandey MK, Kumar D, Vishwakarma DN (2015) Studies on genetic variability, for fodder yield and its contributing characters in bajra [Pennisetum glaucum (L.) R. Br.]. Agricultural Science Digest 35:78-80.

Blair MW, Astudillo C, Grusak M, Graham R, Beebe S (2009) Inheritance of seed iron and zinc content in common bean (Phaseolus vulgaris L.). Molecular Breeding 23:197-207.

Budak H, Pedraza F, Cregan PB, Baenzinger PS, Dweikat I (2003) Development and utilization of SSRs to estimate the degree of genetic relationships in a collection of pearl millet germplasm. Crop Science 43:2284-2290.

Chandra-Shekhra AC, Prasanna BM, Bhat SR, Singh BB (2007) Genetic diversity analysis of elite pearl millet inbred lines using RAPD and SSR markers. Journal of Plant Biochemistry and Biotechnology 16:23-28.

Choudhary R, Jat BL, Anwala R, Dhikwal SR, Sharma KC (2012) Studies on estimates of genetic variability and character association of yield components and protein content in pearl millet. Forage Research 38:80-85.

Chowdari KV, Davierwala AP, Gupta VS, Ranjekar PK, Govila OP (1998) Genotype identification and assessment of genetic relationships in pearl millet [Pennisetum glaucum (L.) R. Br] using microsatellites and RAPDs. Theoretical and Applied Genetics 97:154-162.

Cichy AA, Caldas GV, Snapp SS, Blair MW (2009) QTL analysis of seed iron, zinc and phosphorus levels in an Andean bean population. Crop Science 49:1742-1750.

Darnton-Hill I, Webb P, Harvey PW, Hunt JM, Dalmiya N, Chopra M, Ball MJ, Bloem MW, deBenoist B (2005) Micronututrient deficiencies and gender: Social and economic costs. American Journal of Clinical Nutrition 81:1198S-1205S.

Devos KM, Pittaway TS, Reynolds A, Gale MD (2000) Comparative mapping reveals a complex relationship between the pearl millet genome and those of foxtail millet and rice. Theoretical and Applied Genetics 100:190-198.

Garvin DF, Welch RM, Finley JW (2006) Historical shifts in the seed mineral micronutrient concentration of US hard red winter wheat germplasm. Journal of the Science of Food and Agriculture 86:2213-2220.

Govindaraj M, Rai KN, Shanmugasundaram P, Dwivedi SL, Sahrawat KL, Muthaiah AR, Rai AS (2013) Combining ability and heterosis for grain iron and zinc densitiesin pearl millet. Crop Science $53: 507-517$. 
Govindaraj M, Rai KN, Shanmugasundaram P, Rao AS (2012) Efficiency of single plant selection for grain iron and zinc density in pearl millet. The European Journal of Plant Science and Biotechnology 6:114-117.

Govindaraj M, Selvi B, ArunPrabhu D,Rajarathinam S (2009) Genetic diversity analysis of pearl millet (Pennisetum glaucum [L.] R. Br.) accessions using molecular markers. African Journal of Biotechnology $8: 6046-6052$.

Gupta SK, Nepolean T, Sankar SM, Rathore A, Das RR, Rai KN, Hash CT (2015) Patterns of molecular diversity in current and previously developed hybrid parents of pearl millet [Pennisetum glaucum (L.) R. Br.]. American Journal of Plant Sciences 6:1697-1712.

Gupta SK, Velu G, Rai KN, Sumalini K (2009) Association of grain iron and zinc content with grain yield and other traits in pearl millet [Pennisetum glaucum (L.) R. Br.]. Crop Improvement 36:4-7.

Haussmann BIG, Boubacar A, Boureima SS, Vigouroux Y (2006) Multiplication and preliminary characterization of West and Central African pearl millet landraces. International Sorghum and Millets Newsletter

Haussmann BIG, Boureima SS, Kassari IA, Moumouni KH, Boubacar A (2007) Mechanisms of adaptation to climate variability in West African pearl millet landraces- a preliminary assessment. Journal of SAT Agricultural Research 3: 1-3.

Haussmann BIG, Fred Rattunde H, Weltzien-Rattunde E, Traore PSC, vomBrocke K, Parzies HK (2012) Breeding strategies for adaptation of pearl millet and sorghum to climate variability and change in West Africa. Journal of Agronomy and Crop Science 198:327-339.

Hernandez P, Laurie DA, Martin A, Snape JW (2002) Utility of wheat simple sequence repeat (SSR) markers for genetic analysis of Hordeum chilense and tritordeum.Theoretical and Applied Genetics 104:735-739.

Huang XQ, Borner A, Roder MS, Ganal MW (2002)Assessing genetic diversity of wheat (Triticum aestivum L.) germplasm using microsatellite markers. Theoretical and Applied Genetics 105:699-707.

Jaccard P (1908) Nouvelles recherché essur la distribution florale. Bulletin de la Société Vaudoise des Sciences Naturelles 44:223-270.

Jaikishan I, Paik GR, Madhusudhana R, Elangovan M, Rajendrakumar P (2013) Development of microsatellite markers targeting $(\mathrm{GATA})_{\mathrm{n}}$ motifs in sorghum [Sorghum bicolor (L.) Moench]. Molecular Breeding 31: 223-231.
Joshi SP, Gupta VS, Aggarwal RK, Ranjekar PK, Brar DS (2000) Genetic diversity and phylogenetic relationship as revealed by inter simple sequence repeat (ISSR) polymorphism in the genus Oryza. Theoretical and Applied Genetics 100: 1311-1320.

Kanatti A, Rai KN, Radhika K, Govindaraj M, Sahrawat KL, Rao AS (2014) Grain iron and zinc density in pearl millet: combining ability, heterosis and association with grain yield and grain size. Springer Plus 3 : 763.

Kapila RK, Yadav RS, Plaha P, Rai KN, Yadav OP, Hash CT, Howarth CJ (2008) Genetic diversity among pearl millet maintainers using microsatellite markers. Plant Breeding 127:33-37.

Kumar A, Reddy BVS, Ramaiah B, Reddy SP, Sahrawat KL, Upadhyaya HD (2009) Genetic variability and plant character association of grain $\mathrm{Fe}$ and $\mathrm{Zn}$ in selected core collection accessions of sorghum germplasm and breeding lines. Journal of SAT Agricultural Research 7:1-4.

Kumar A, Reddy BVS, Ramaiah B, Sahrawat KL, Pfeiffer WH (2013) Gene effects and heterosis for grain iron and zinc concentration in sorghum [Sorghum bicolour (L.) Moench]. Field Crops Research 146:86-95.

Kumar S (2011) Development of new mapping population and marker-assisted improvement of iron and zinc grain density in pearl millet [Pennisetum glaucam (L.) R. Br.] $\mathrm{PhD}$ Thesis submitted to the Swami Keshwanand Rajasthan Agricultural University, Bikaner, Rajasthan, India.

Kumar Y, Lamba RAS, Yadav HP, Kumar R, Devvart (2014) Studies on variability and character association under rainfed conditions in pearl millet (Pennisetum glaucumL.) hybrids.Forage Research 39:175-178.

Lakshmana D, Birador BD, Madaiah D, Jolli RB (2010) Genetic variation in pearl millet germplasm. Indian Journal of Plant Genetic Resources 23:315-317.

Liu CJ, Witcombe JR, Pittaway TS, Nash M, Hash CT, Busso CS, Gale MD (1994) An RFLP-based genetic map of pearl millet (Pennisetum glaucam). Theoretical and Applied Genetics 89:481-487.

Mariac C, Loung V, Kapran I, Mamadou A, Sagnard F, Deu M, Chantereau J, Gerard B, Ndjeunga J, Bezancon G, Pham J, Vigouroux Y (2006) Diversity of wild and cultivated pearl millet accessions [Pennisetum glaucam (L.) R. Br.] in Niger assessed by microsatellite markers. Theoretical and Applied Genetics 114:49-58.

Martel E, De Nay D, Silijak-Yakovlev S, Brown S, Sarr A (1997) Genome size variation and basic chromosome number in pearl 
millet and fourteen related Pennisetum species. Journal of Heredity 88:139-143.

Nepolean T, Gupta SK, Dwivedi SL, Bhattacharjee R, Rai KN, Hash CT (2012)Genetic diversity in maintainer and restorer lines of pearl millet. Crop Science 52:255-2563.

Ni J, Colowit PM, Mackill DJ (2002)Evaluation of genetic diversity in rice subspecies using microsatellite markers. Crop Science 42:601-607.

Oikeh SO, Menkir A, Maziya-Dixon B, Welch RM, Glahn RP, GauchJr G (2004) Environmental stability of iron and zinc concentration in grain of elite early-maturing tropical maize genotypes grown under field conditions. Journal of Agricultural Sciences 142:543-551.

Oikeh SO, Menkir A, Maziya-Dixon D, Welch R, Glahn RP (2003) Assessment of concentration of iron and zinc and bioavailable iron in grains of early-maturing tropical maize varieties. Journal of Agricultural and Food Chemistry 51:3688-3694.

Paltridge NG, Palmer LJ, Milham PJ, Guild GE, Stangoulis JCR (2012) Energy-dispersive X-ray fluorescence analysis of zinc and iron concentration in rice and pearl millet grain. Plant and Soil 361: $251-260$

Peleg Z, Cakmak I, Ozturk L, Yazici A, Jun Y, Budak H, Korol AB, Fahima T, Saranga Y (2009) Quantitative trait loci conferring grain mineral nutrient concentrations in durum wheat $\mathrm{X}$ wild emmer wheat RIL population. Theoretical and Applied Genetics 119:353-369.

Qi X, Lindup S, Pittaway TS, Allouis S, Gale MD, Devos KM (2001) Development of simple sequence repeat markers from bacterial artificial chromosomes without subcloning. BioTechniques 31:355-362.

Qi X, Pittaway TS, Lindup S, Liu H, Waterman E, Padi FK, Hash CT, Zhu J, Gale MD, Devos KM (2004) An integrated genetic map and a new set of simple sequence repeat markers for pearl millet (Pennisetm glaucam).Theoretical and Applied Genetics 109:1485-1493.

Rai KN, Govindaraj M, Rao AS (2012) Genetic enhancement of grain iron and zinc content in pearl millet. Quality Assurance and Safety of Crops \& Foods 4:119-125.

Rai KN, Velu G, Govindaraj M, Upadhyaya HD, Rao AS, Shivade H, Reddy KN (2015) Iniadi pearl millet germplasm as a valuable genetic resource for high grain iron and zinc densities. Plant Genetics Resources 13:75-82.
Rai KN, Yadav OP, Rajpurohit BS, Patil HT, Govindaraj M, Khairwal IS, Rao AS, Shivade H, Pawar VY, Kulkarni MP (2013) Breeding pearl millet cultivars for high iron density with zinc density as an associated trait. Journal of SAT Agricultural Research 11:1-7.

Ramya AR, Ahamed ML, Srivastava RK (2017) Genetic Diversity Analysis among Inbred Lines of Pearl millet [Pennisetumglaucum (L.) R. Br.] Based on Grain Yield and Yield Component Characters. International Journal of Current Microbiology and Applied Sciences 6: 2240-2250.

Rohlf FJ (2000) NTSYS-pc: numerical taxonomy and multivariate analysis system, version 2.1. Exeter Software: Setauket, NY.

Rongwen J, Akkaya AA, Bhagwat U, Lavi U, Cregan PB (1995) The use of microsatellite DNA markers for soybean genotype identification. Theoretical and Applied Genetics 90:43-48.

Saghai-Maroof MA, Soliman KM, Jorgensen RA, Allard RW (1984) Ribosomal DNA spacer-length polymorphisms in barley: mendelian inheritance, chromosomal location, and population dynamics. Proceedings of the National Academy of Sciences, USA 81:8014-8019.

Saghai-Maroof MA, Biyashev RM, Yang GP, Zhang Q, Allard RW (1994) Extraordinarily polymorphic microsatellite DNA in barley: Species diversity, chromosomal locations, and population dynamics. Proceedings of the National Academy of Sciences, USA 91:5466-5470.

Senthilvel S, Jayashree B, Mahalakshmi V, Kumar PS, Nakka S, Nepolean T, Hash CT (2008) Development and mapping of Simple Sequence Repeat markers for pearl millet from data mining of Expressed Sequence Tags. BMC Plant Biology 8:119.

Sheron OP, Tonk DS, Kaushik LS, Hasija RC, Pannu RS (1998) Statistical software package for agricultural research workers. Recent Advances in information theory, Statistics \& Computer Applications by D.S.R. Hooda\& R.C. Hasija Department of Mathematics Statistics, CCS HAU, Hisar (139-143)

Singh A, Dikshit HK, Jain N, Singh D, Yadav RN (2014) Efficiency of SSR, ISSR and RAPD markers in molecular characterization of mungbean and other Vigna species. Indian Journal of Biotechnology 13:81-88.

Singh AK, Rana MK, Singh S, Kumar S, Durgesh K, Arya L (2013) Assessment of genetic diversity among pearl millet [Pennisetum glaucum (L.) R Br.] cultivars using SSR markers. Range Management \& Agroforestry 34:77-81. 
Singh K, Chhuneja P, Tiwari VK, Rawat N, Neelam K, Aggarwal R, Malik S, Keller B, Dhaliwal HS (2010) Mapping of QTL for grain iron and zinc content in diploid A genome wheat and validation of these loci in $\mathrm{U}$ and $\mathrm{S}$ genomes. In: Plant and Animal Genomes XVIII Conference, 9-13 January 2010, San Diego, CA.

Souframanien J, Gopalkrishna T (2004) A comparative analysis of genetic diversity in blackgram genotypes using RAPD and ISSR markers. Theoretical and Applied Genetics 109: 1687-1693.

Stangoulis JCR, Huynh BL, Welch RM, Choi EY, Graham RD (2007) Quantitative trait loci for phytate in rice grain and their relationship with grain micronutrient. Euphytica154:289-294.

Stein AG (2010) Global impacts of human mineral malnutrition. Plant Soil 335:133-154.

Stich B, Haussmann BIG, Raj P, Sankalp P, Hash CT, Melchinger AE, Parzies HK (2010) Patterns of molecular and phenotypic diversity in pearl millet [Pennisetum glaucum(L.) R. Br.] from West and Central Africa and their relation to geographical and environmental parameters. BMC Plant Biology 10:1-10.

Sumanth M, Sumathi P, Vinodhana NK, Sathya M (2013) Assessment of genetic distance among the inbred lines of pearl millet (Pennisetum glaucam (L.) R. Br.) using SSR markers. International Journal of Biotechnology and Allied Fields 3:152-162.

Thiyagu K, Narayanan Manikanda Boopathi N, Nadarajan AG, Selvakumar P, Magadum S, Ravikesavan R (2011) Sampling and exploitation of genetic variation exist in locally adapted accessions using phenotypic and molecular markers for genetic improvement of cotton. Geneconserve 10:129-153.

Upadhyaya HD, Ramesh S, Shivali S, Singh SK, Varshney SK, Sarma NDRK, Ravishankar CR, Narasimhudu Y, Reddy VG, Sahrawat KL, Dhanalakshmi TN, Mgonja MA, Parzies HK, Gowda CLL, Singh S (2011) Genetic diversity for grain nutrients contents in a core collection of finger millet (Eleusine coracana (L.) Gaertn. ) germplasm. Field Crop Research 121:42-52.

Velu G, Ortiz-Monasterio I, Singh RP, Payne T (2011) Variation for grain micronutrients in wheat core collections accession of diverse origin. Asian Journal of Crop Science 3:43-48.

Velu G, Rai KN, Muralidharan V, Kulkarni VN, Longvah T, Raveendran TS (2007) Prospects of breeding biofortified pearl millet with high grain iron and zinc content. Plant Breeding 126:182-185.

Velu G, Rai KN, Sahrawt KL (2008a)Variability for grain iron and zinc content in a diverse range of pearl millet populations. Crop Improvement 35:186-191.

Velu G, Rai KN, Sahrawt KL, Sumalini K (2008b) Variability for grain iron and zinc contents in pearl millet hybrids. Journal of SAT Agricultural Research 6:1-4.

vomBrocke K, Christinck A, Weltzien ER, Presterl T, Geiger HH (2003) Farmers' seed systems and management practices determine pearl millet genetic diversity patterns in semi-arid regions of India. Crop Science 43:1680-1689.

Welch RM, Graham RD (2004) Breeding for micronutrients in staple food crops from a human nutrition perspective. Journal of Experimental Botany 55:353-364.

WHO (2002) Reducing risks and promoting healthy life. The World Health Report. World Health Organization, Geneva, Switzerland. pp. 168.

Wu YX, Daud MK, Chen L, Zhu SJ (2007) Phylogenetic diversity and relationship among Gossypium germplasm using SSRs markers. Plant Systematics and Evolution 268:199-208.

Yadav OP, Rai KN (2013) Genetic improvement of pearl millet in India. Agricultural Research 2:275-292.

Yadav S, Jain S, Jain V, Jain RK (2007) Genetic analysis of CMS, restorer, hybrid and open-pollinated genotypes of Indian pearl millet [Pennisetum glaucam (L.) R. Br.] using ISSR markers. Indian Journal of Biotechnology 6:340-348.

Yap IV, Nelson RJ (2002) Winboot: a program for performing bootstrap analysis of binary data to determine the confidence of UPGMA-based dendrograms. IRRI, Manila. 